\title{
The Global Museum: natural history collections and the future of evolutionary science and public education
}

Freek T. Bakker ${ }^{\text {Corresp., } 1}$, Alexandre Antonelli ${ }^{2}$, Julia Clarke ${ }^{3}$, Joseph A. Cook ${ }^{4}$, Scott V. Edwards ${ }^{5,6}$, Per G. P. Ericson ${ }^{7}$, Søren Faurby ${ }^{8}$, Nuno Ferrand ${ }^{9}$, Magnus Gelang ${ }^{10}$, Rosemary G. Gillespie ${ }^{11}$, Martin Irestedt ${ }^{12}$, Kennet Lundin ${ }^{10}$ ${ }^{13}$, Ellen Larsson ${ }^{8}$, Pável Matos-Maraví ${ }^{14}$, Johannes Müller ${ }^{15}$, Ted von Proschwitz ${ }^{10}$, George K. Roderick ${ }^{11}$, Alexander Schliep ${ }^{16}$, Niklas Wahlberg ${ }^{17}$, John Wiedenhoeft ${ }^{16}$, Mari Källersjö ${ }^{18}$

1 Biosystematics Group, Wageningen University \& Research, Wageningen, The Netherlands

Department of Science, Royal Botanic Gardens, Kew, Richmond, United Kingdom

3 Jackson School of Geosciences, University of Texas at Austin, Austin, Texas, United States

4 Museum of Southwestern Biology, Department of Biology, University of New Mexico, Albuquerque, New Mexico, United States

5 Department of Organismic and Evolutionary Biology, Museum of Comparative Zoology, Harvard University, Cambridge, Massachusetts, United States

${ }^{6}$ Gothenburg Centre for Advanced Studies in Science and Technology, Chalmers University of Technology and University of Gothenburg, Göteborg, Sweden

7 Department of Bioinformatics and Genetics, Swedish Museum of Natural History, Stockholm, Sweden

8 Department of Biological and Environmental Sciences, Gothenburg Global Biodiversity Centre, University of Gothenburg, Göteborg, Sweden

9 Museu de História Natural e da Ciência, Universidade do Porto, Porto, Portugal

10 Department of Zoology, Gothenburg Natural History Museum, Göteborg, Sweden

11 Essig Museum of Entomology, Department of Environmental Science, Policy and Management, University of California, Berkeley, Berkeley, California, United States

12 Dept. of Bioinformatics and Genetics, Swedish Museum of Natural History, Stockholm, Sweden

13 Gothenburg Global Biodiversity Centre, University of Gothenburg, Göteborg, Sweden

14 Department of Ecology, Institute of Entomology ASCR, České Budějovice, Czechia

15 Leibniz-Institut für Evolutions- und Biodiversitätsforschung, Museum für Naturkunde, Berlin, Germany

16 Department of Computer Science and Engineering, University of Gothenburg, Göteborg, Sweden

17 Department of Biology, Lund University, Lund, Sweden

18 Gothenburg Botanical Garden, Göteborg, Sweden

Corresponding Author: Freek T. Bakker

Email address: freek.bakker@wur.nl

Natural history museums are unique spaces for interdisciplinary research and for educational innovation. Through extensive exhibits and public programming and by hosting rich communities of amateurs, students, and researchers at all stages of their careers, they can provide a place-based window to focus on integration of science and discovery, as well as a locus for community engagement. At the same time, like a synthesis radio telescope, when joined together through emerging digital resources, the global community of museums (the 'Global Museum') is more than the sum of its parts, allowing insights and answers to diverse biological, environmental, and societal questions at the global scale, across eons of time, and spanning vast diversity across the Tree of Life. We argue that, whereas natural history collections and museums began with a focus on 
describing the diversity and peculiarities of species on Earth, they are now increasingly leveraged in new ways that significantly expand their impact and relevance. These new directions include the possibility to ask new, often interdisciplinary questions in basic and applied science, such as in biomimetic design, and by contributing to solutions to climate change, global health and food security challenges. As institutions, they have long been incubators for cutting-edge research in biology while simultaneously providing core infrastructure for research on present and future societal needs. Here we explore how the intersection between pressing issues in environmental and human health and rapid technological innovation have reinforced the relevance of museum collections. We do this by providing examples as food for thought for both the broader academic community and museum scientists on the evolving role of museums. We also identify challenges to the realization of the full potential of natural history collections and the Global Museum to science and society and discuss the critical need to grow these collections. We then focus on mapping and modelling of museum data (including place-based approaches and discovery), and explore the main projects, platforms and databases enabling this growth. Finally, we aim to improve relevant protocols for the long-term storage of specimens and tissues, ensuring proper connection with tomorrow's technologies and hence further increasing the relevance of natural history museums. 
1 AUTHOR COVER PAGE

2 Article submission to PeerJ

3 Manuscript category: Literature Review Articles

4 Collection: "Endless forms: Advances in evolutionary analyses of biodiversity"

5 Article title:

6 The Global Museum: natural history collections and the

7 future of evolutionary science and public education

9 Authors: Freek T. Bakker ${ }^{1, *}$, Alexandre Antonelli $2,3,4,5,11$, Julia Clarke ${ }^{6}$, Joseph A. Cook ${ }^{8}$, Scott

10 V. Edwards ${ }^{2,16}$, Per G.P. Ericson ${ }^{10}$, Søren Faurby ${ }^{3,4}$, Nuno Ferrand ${ }^{12}$, Magnus Gelang ${ }^{9}$, Rosemary

11 G. Gillespie ${ }^{13}$, Martin Irestedt ${ }^{10}$, Kennet Lundin ${ }^{3,9}$, Ellen Larsson ${ }^{3,4}$, Pável Matos-Maraví3,4,17,

12 Johannes Müller ${ }^{14}$, Ted von Proschwitz ${ }^{9}$, George K. Roderick ${ }^{13}$, Alexander Schliep ${ }^{15}$, Niklas

13 Wahlberg ${ }^{7}$, John Wiedenhoeft ${ }^{15}$ and Mari Källersjö ${ }^{5}$

$15{ }^{1}$ Biosystematics Group, Wageningen University \& Research, Wageningen, The Netherlands

$16{ }^{2}$ Department of Organismic and Evolutionary Biology, Museum of Comparative Zoology,

17 Harvard University, Cambridge, Massachusetts, United States 
$18{ }^{3}$ Gothenburg Global Biodiversity Centre, University of Gothenburg, Göteborg, Sweden

19 'Department of Biological and Environmental Sciences, Gothenburg Global Biodiversity Centre,

20 University of Gothenburg, Göteborg, Sweden

$21 \quad{ }^{5}$ Gothenburg Botanical Garden, Göteborg, Sweden

$22{ }^{6}$ Jackson School of Geosciences, University of Texas at Austin, Austin, Texas, United States

$23 \quad{ }^{7}$ Department of Biology, Lund University, Lund, Sweden

$24{ }^{8}$ Museum of Southwestern Biology, Department of Biology, University of New Mexico,

25 Albuquerque, United States

${ }^{9}$ Department of Zoology, Gothenburg Natural History Museum, Göteborg, Sweden

${ }^{10}$ Department of Bioinformatics and Genetics, Swedish Museum of Natural History, Stockholm,

Sweden

${ }^{11}$ Department of Science, Royal Botanic Gardens, Kew, Richmond, United Kingdom

${ }^{12}$ Museu de História Natural e da Ciência, Universidade do Porto, Porto, Portugal

${ }^{13}$ Essig Museum of Entomology, Department of Environmental Science, Policy and

Management, University of California, Berkeley, Berkeley, California, United States.

${ }^{14}$ Museum für Naturkunde, Leibniz-Institut für Evolutions- und Biodiversitätsforschung, Berlin,

Germany

${ }^{15}$ University of Gothenburg, Department of Computer Science and Engineering, Göteborg,

Sweden 
$37{ }^{16}$ Gothenburg Centre for Advanced Studies in Science and Technology, Chalmers University of

38 Technology and University of Gothenburg, Göteborg, Sweden

$39{ }^{17}$ Department of Ecology, Institute of Entomology ASCR, České Budějovice, Czechia

$40 *$ Author for correspondence. E-mail: freek.bakker@wur.nl

\section{Abstract}

Natural history museums are unique spaces for interdisciplinary research and for educational innovation. Through extensive exhibits and public programming and by hosting rich communities of amateurs, students, and researchers at all stages of their careers, they can provide a place-based window to focus on integration of science and discovery, as well as a locus for community engagement. At the same time, like a synthesis radio telescope, when joined together through emerging digital resources, the global community of museums (the 'Global Museum') is more than the sum of its parts, allowing insights and answers to diverse biological, environmental, and societal questions at the global scale, across eons of time, and spanning vast diversity across the Tree of Life. We argue that, whereas natural history collections and museums began with a focus on describing the diversity and peculiarities of species on Earth, they are now increasingly leveraged in new ways that significantly expand their impact and relevance. These new directions include the possibility to ask new, often interdisciplinary questions in basic and applied science, such as in biomimetic design, and by contributing to solutions to climate change, global health and food security challenges. As institutions, they have 
58 long been incubators for cutting-edge research in biology while simultaneously providing core

59 infrastructure for research on present and future societal needs.

60 Here we explore how the intersection between pressing issues in environmental and

61 human health and rapid technological innovation have reinforced the relevance of museum

62 collections. We do this by providing examples as food for thought for both the broader academic

63 community and museum scientists on the evolving role of museums. We also identify challenges

64 to the realization of the full potential of natural history collections and the Global Museum to

65 science and society and discuss the critical need to grow these collections. We then focus on

66 mapping and modelling of museum data (including place-based approaches and discovery), and

67 explore the main projects, platforms and databases enabling this growth. Finally, we aim to

68 improve relevant protocols for the long-term storage of specimens and tissues, ensuring proper

69 connection with tomorrow's technologies and hence further increasing the relevance of natural

70 history museums.

72 Keywords: collections, field education, Global Museum, innovation-incubator, natural history,

73 place-based, specimens, transcriptomics, epigenomics. 
74

\section{Introduction}

Natural history museums harbour the authoritative records of biological diversity across time and space and have always been meeting places for scientists, amateurs, and the public. By visiting a natural history museum and learning about nature, the lay citizen often tacitly endorses the information presented, so that museums are trusted resources, at a time when many other institutions are bitterly mistrusted (Foley, 2015). Natural history collections have a special role, in part because they not only serve public education, but in many cases they also are actively investigated to answer pressing problems in biology and beyond (e.g. Vane-Wright \& Cranston, 1992).

Museum biological collections are more than meets the eye. Each specimen harbours many kinds of data, such as information on locality and collection parameters, or on associated pathogens, as well as biopolymers such as DNA and proteins, and metabolic compounds. This wealth of metadata across many specimens turns collections into powerful research tools, enabling scientists to test for historic environmental hypotheses and carry out diverse studies ranging from public health \& safety (as cornerstones in studies of environmental health and epidemiology; Suarez \& Tsutsui, 2004); biomimetic design, where naturally-occurring architectures and systems inspire technological innovation (Jayaram \& Full, 2016; Nirodi et al., 2018); historical genomics (focussing on ancient alleles or past genotypes; Bi et al. 2013; Besnard et al. 2014); to global and local change (tracking shifts in phenotype across specimens through time; Jones \& Daehler, 2018), something that a database of mere species observations cannot do. But natural history collections face challenges, many related to the need for long-term commitment to care and growth. 
97

98

\section{Survey Methodology}

This paper provides examples of how natural history museums have enabled discovery in evolutionary biology and environmental science; how that role has recently expanded to other fields of science; and how museums have helped foster the next generation of innovative thinkers.

\section{Collections \& types of museums}

We broadly define natural history museums as institutions containing diverse physical specimens, including seed banks, substantial living, frozen, or dried tissue collections, and DNA banks, among others. These collections often include material from rapidly disappearing or extinct species, and often collected from the most inaccessible parts of the Earth. Collections may have innate, historic biases in taxonomic coverage and sampling design, which might need to be considered for their further development. Whereas historically natural history museums, in particular those in Europe, were linked to the colonialist enterprise, increasingly international specimen acquisition and study are conducted in strong partnership with local institutions. International agreements, such as the Nagoya protocol, rightly mandate such participation under the terms of Access and Benefit Sharing. Additionally, citizen science increasingly contributes to collections (see Box 1), which today are housed all over the world, and serve as gems of diverse global centres of cutting-edge research (see Fig. 1) and education, for an increasingly urban human population (e.g. Bates, 2007). Natural history museums may be located at universities without exhibits, or may include public exhibits, such as typically occurs in national, state or regional entities. In many cases, regional collections, and their exhibits, reflect and strengthen 
119 visibility, appreciation, identity and awareness of local culture, flora and fauna, therefore playing

120 an important and confirmative role for the visiting public. Collections that span long periods of

121 time reflect the history of science as well as changes in norms and values in society: what was

122 sampled, how and why. This emphasis is especially visible in open, regional, collections on

123 display. Regionality, therefore, can be considered a strength of collections by fulfilling an

124 important role in sustaining knowledge and appreciation of the value of local biodiversity.

125 Increasingly, regional museums were connected into the global network of collections.

126 Distribution, redundancy and digitization of collections: The distributed nature of the world's

127 museum collections increases long term data security. Collections of natural objects are

128 vulnerable to theft, fire and water damage, but the distributed nature of collections and in some

129 cases duplicate repository of specimens ensures persistence, such as for the tens of thousands of

130 specimens of plants stored at the Berlin Herbarium that were almost completely destroyed during

131 World War II. In contrast, the Butantã Museum in São Paulo had a world-renowned collection of

13285,000 snakes and 500,000 arachnids that were not duplicated and shockingly destroyed by a fire

133 in 2010 (Phillips, 2010). Despite these concrete recent examples of natural heritage loss, the

134 infrastructure of many museums remains underfunded, exacerbating their vulnerability. Another

135 grim example is the Brazil National Museum in Rio de Janeiro, where a fire destroyed an

136 estimated $90 \%$ of the collections in several divisions in September 2018 (Phillips, 2018), causing

137 dramatic loss of both knowledge and data.

138 Creating overlap in collections, especially for extant species and genetic resource collections, is

139 key to ensuring the longevity of these samples and associated data. Initiatives such as the Global

140 Genome Biodiversity Network (GGBN; Droege et al., 2016) aim to collect, catalogue, and

141 “democratise" genomic resources across global collections, covering 45,708 species (as of 30 
142 September 2019). This enterprise represents an important step in the direction of a distributed 143 collection, but would benefit from more coordination and financial support for data security,

144

145

146

147

148

149

150

151

152

153

154

155

156

157

158

159

160

161

162

163

164

complementarity, and redundancy among collections. These aims are included in the mission of the pan-European Distributed System of Scientific Collections (www.dissco.eu) initiative, which aims at "Providing hard evidence on our planet's natural diversity", by enabling the transformation of a "fragmented landscape of the crucial natural science collections in Europe into an integrated knowledge base". DiSSCo claims it "will allow Europe's researchers and technology professionals to share and reuse the data linked to collections across disciplines and borders. It will mobilise and harmonise science collection data (collection metadata, traits, images, metabolites, nucleotide sequences, distribution or ecological information) and make them available as part of a highly connected linked-data graph.” In the US, the Integrated Digitized Biocollections (iDigBio) initiative supported by the National Science Foundation (NSF) has helped make data and images for millions of biological specimens available in electronic format "for the research community, government agencies, students, educators, and the general public" (Page et al., 2015). iDigBio serves as "the coordinating center for the national digitization effort" fostering partnerships, innovations, and content, but, crucially, is not assured of long-term funding by the NSF or other federal agencies. In contrast, DiSSCo, which has now been accepted into the EU's Infrastructure Roadmap, started by securing government buy-in, with content being part of operational costs. Because it has become an established and recognized entity, governments fund the infrastructure because they need the services.

Despite their immense value, natural history museums are facing grand challenges. Taxonomic expertise is decreasing for many organism groups or is not represented in the curation of some collections. Funding often relies on public sources and may be adversely affected by political 
165

166

167

168

169

170

171

172

173

174

and socio-economic changes, comprising the long-term continuity of a museum's activities (see for instance Andreone et al., 2014). New international regulations on the collection, export and use of specimens for non-commercial and commercial purposes are now increasing administrative burdens and may prevent further development of collections. Cross-institutional, international coordination of secure data standards has not yet been fully realised. At the global level, the Global Biodiversity Information Facility (GBIF) is "an international network and research infrastructure funded by the world's governments and aimed at providing anyone, anywhere, open access to data about all types of life on Earth.” As the main global biodiversity database, a large proportion of the $>1$ billion records comprise observations rather than specimens (see below). Smith et al. (2016) and Yesson et al. (2007) discuss issues regarding data quality in GBIF, such as unreliable taxonomic identifications in the absence of voucher specimens, and non-global coverage of species distribution data. Verifying suspect occurrences through niche modelling, based on verified and geo- and DNA-referenced occurrences of the same species, is a step toward identifying unreliable records.

\section{The value and diversity of biological specimens}

All collections ultimately contain, or are dependent on, specimens. A specimen may consist of a complete organism (collected by naturalists over the past few centuries) or parts of a single individual organism. Increasingly, meta-data associated with the physical specimen, the 'extended specimen' (Webster, 2017), add value and increase data richness through videos, sound recordings, information on habitat, and photographs. For example, for birds, the extended specimen may be comprised of records of the song, or videos of behaviour of those organisms, prepared in a way that preserves them for the future. Bioacoustic tools provide unique collections 
188 that can include some of the last known evidence of extant species. Likewise, several films exist

189 (e.g. https://www.youtube.com/watch?v=nAzqGn-LHCw) portraying the behaviour of animal

190 species, such as the Tasmanian tiger Thylacinus cynocephalus, the golden toad Incilius

191 periglenes, and the Hawaiian crow Corvus hawaiiensis, that are now extinct in the wild.

192 Museums currently host increasingly diverse collections, which, in addition to DNA and tissue

193 banks, may be generated by core genomic facilities or imaging labs (isotopic, x-ray computed

194 tomography data [CT], scanning electron microscopy [SEM] images). Examples now include

195 rich stores of high-resolution CT data generated from museum specimens, which allow

196 investigators to look inside material in a largely non-destructive way. These require different

197 storage resources from those that traditionally constitute museum infrastructures, namely large-

198 scale and secure long-term storage of image data. Integration of different data streams will allow

199 bridging among disciplines and the involvement of fields underrepresented in natural history

200 museums, such as engineering, biomedical sciences, and art. For instance, biomimetic design can

201 benefit strongly from inspiration from natural history collections (for examples from robotics see

202 Jayaram \& Hull, 2016), or solutions to global health or food security challenges can be based on

203 exploration of natural history specimen collections (see Box 2 Specimens and pathogens).

204 Specimens are at the heart of the discovery process and technological advances are increasing the 205 number and diversity of possible questions that can be addressed (e.g., Schmitt et al. 2018; see

206 below). For instance, bone fragment identification using collagen barcoding was difficult to

207 imagine before the rise of LC-MS and other technologies, but Welker et al. (2015) and Horn et

208 al. (2019) used proteomics to identify Palaeolithic fragments of mammal bones and extinct

209 species, respectively. Genomic analyses of single bone fragments can inform on the evolutionary

210 and demographic history of our own species (e.g., Slon et al., 2018). Future technologies may 
211 include more advanced chemical, biochemical, isotope or micro-anatomical surveys, making

212 specimens even more critical because they connect diverse data streams and facilitate data

213 interoperability (see Box 3 for 'best curation practices for the future'). At the same time,

214 maintaining specimens is key to repeatability - a core requirement of science.

215 Specimen collections enable answers to a large number of other scientific questions, some of

216 which have not yet been posed. The earliest museums facilitated interactions among scholar-

217 travellers, to share observational data from across the planet and to help build the core of what

218 would become natural history and modern evolutionary biology. Increasingly, museums are

219 leveraging new data from their specimens, and this integration of data types allows training in

220 techniques that bridge among disciplines, as well as the generation of data sets that are of

221 relevance to disparate traditional fields such as engineering, biomedical sciences, and art. Today

222 natural history museums serve increasingly as a nexus for work that disregards disciplinary

223 boundaries and addresses questions we did not know to ask before. Because collections provide

224 the opportunity to rigorously examine diverse aspects of taxonomic, morphological, genetic, and

225 chemical variation across vast temporal and spatial scales, they can help diverse scientists bridge

226 the gaps between traditionally distinct disciplines. Museum spaces ideally are filled with students

227 who learn to think anti-disciplinarily and appreciate the importance of the specimen. These

228 spaces can therefore be considered 'Innovation Incubators' where a next generation of critical

229 thinkers in biology and beyond will be trained, embedded within the prerequisite of traditional

230 taxonomic museum expertise.

231 A specimen constitutes a voucher, not only of the actual individual sampled at the time, but often

232 also of its locality - including information about the soil and other biotic and abiotic conditions

233 in which the specimen was collected (see below, the 'holistic specimen'). In fact, the specimen 
234

235

236

237

238

239

240

241

242

243

244

245

246

247

248

249

250

251

252

253

254

255

256

can be seen as the outcome of a combination of genotype and past environmental change or conditions (e.g., Holmes et al., 2017), and a well-curated collection captures the variation in phenotype as well as genotype (see Bi et al. 2013; Rowe et al. 2011; Staats et al. 2013; Ruane and Austin, 2017). For instance, Cridland et al. (2018) comparing SNP patterns from historic museum and living specimens of bees, could not only infer 'rapid change' in genetic composition of honey bees in California, but also identify historic genotypes in candidate genes possibly involved in adaptation to new niches. Another, non-domestic, example involved reconstructing the shift to C4 photosynthesis in grasses using DNA from a 100-year-old Malagasy herbarium specimen for which both phylogenetic placement and genetic regulation of C4 photosynthesis could be assessed (Besnard et al., 2014). Therefore, specimen collections can provide a powerful reference for functional genomics studies, in a world where assessing phenotypes of different genotypes, retrievable from the specimen, is essential.

Specimens vs. observations in digital collections: Troudet et al. (2018) describe how over the past decades the proportion of specimen-based occurrences in GBIF has decreased from 68 to $18 \%$, in favour of observation-based occurrences, either expert-validated or not, mostly from contributions by citizen science efforts such as iNaturalist and eBird (see Table 1, and Box 1). This will have affected repeatability and 'richness' of systematics and evolutionary studies and the authors urge that "when impossible to secure, voucher specimens can be replaced by observation-based occurrences", particularly when combined with 'ancillary' data such as recordings, pictures, DNA samples etc. In cases where ethical, conservational, or practical concerns exist, observation data instead of collected specimens provide additional (or occasionally substitute) contributions to our knowledge on where and when particular species occur. Recorded sightings, such as those from iNaturalist or e-Bird, include occurrences of 
257 diverse temporal range, and are pretty much the only observation-based data that are allowed in

258 GBIF. In addition to such observations recorded in the field, however, collected specimens,

259 when available, offer additional options for confirming or extending the original work using new

260 analytical techniques. Similarly, sound recordings can be re-studied within the context of new

261 evidence, leading to reciprocal illumination. Boakes et al. (2010) asked how species distribution

262 data for a well-known clade (Gallus) from museum collections compared across literature

263 records, banding (ringing) data, ornithological atlases, and birdwatchers' trip reports in terms of

264 completeness and consistency. They found that "..primary sources of biodiversity information

265 are subject to a range of biases that fundamentally affect their interpretation and therefore their

266 reliability in measuring biodiversity change" (Boakes \& al. 2010).

\section{The need for continued and comprehensive collecting}

Continued field collecting ensures that museum specimens and data will be accessible for future generations and secures future access to time series of specimens, collected continuously over decades or even hundreds of years. These long-term archives provide valuable and unique information (Graham et al. 2004) on changes in species composition in environments and habitats, due to factors such as climate change, human-mediated nitrogen deposition, or other anthropogenic activities (Meineke et al. 2019a; 2019b). An example is a large survey and collection of marine invertebrates from the Swedish west coast from the 1920's and 30's conducted by the Gothenburg Natural History museum (GNM), in which the exact sample locations could be deduced, and consequently revisited during a new survey in the 2000's, revealing a $60 \%$ loss of biodiversity (Obst et al. 2017). Indeed, specimens collected by 
279 researchers 200 years in the past can be compared with contemporary (and future) sampling-- as 280 long as these collections and institutions persist.

281 Whereas the value of field collecting may be obvious within the broader museum community, 282 justification for collecting specimens is not always clear for society and even some scientists 283 (e.g. Rocha et al. 2014). There can be additional challenges for collectors in Buddhist countries 284 where killing living things is problematic because of prevailing philosophies. In some sectors of the US, it is clear that the public misunderstands the mission of museums and does not appreciate the need for continued responsible collecting. One recent example is the unwarranted overreaction against scientific collecting of a bird specimen from the Solomon Islands, information about which was placed on the web by well-meaning media directors at the American Museum of Natural History (Johnson, 2018). This sad event, which resulted in death threats and cyber-harassment of the scientist involved, shows that many people see only the destructive aspects of collecting of individual specimens, but do not connect this act with the many beneficial services of museums to science and society. Additionally, some laypeople did not appreciate the relative insignificance of scientific collecting as an agent of species loss as compared with habitat loss and introduced or feral predators, such as house cats (see Marra \& Santella 2016; Woinarski et al. 2019). In this case, the public seemed to place undue emphasis on the loss of life incurred by collection of a single bird, suggesting much more relevance of an emotional response rather than a scientific appraisal of the true impact of collecting data on populations.

Amending the idiosyncracies and biases of natural history collections: Historically, some of the largest collections have grown through the acquisition of specimens through professional collections, such as the ornithology collections at the Museum of Comparative Zoology at 
302 Harvard. In the past 50 years, natural history collections have instead grown more through the 303 research programs of individual scientists. Collections growth by these means can result in 304 spectacular coverage of specific clades or localities, but often results in patchy coverage of

305

306

307

308

309

310

311

312

313

314

315

316

317

318

319

320

321

322

323

324

biodiversity as a whole, or coverage in a way that is maximally useful for studying the effects of global change on organismal diversity. Collections have also tended to emphasizing rarities (i.e. occurring as single individuals per species), a biological phenomenon which may actually be commonly-occurring, for instance in tropical herbivorous insects (Novotný \& Basset, 2000).

Such biases often result from efforts to conduct general collecting (ter Steege et al., 2011). Like research-driven collecting, these efforts at generality has resulted in an invaluable reference specimen base in today's museum collections, allowing comparison with living specimens, identifying relatives of medically- and economically-important species (for instance melon, Sebastian et al., 2010), or testing historic biological hypotheses (e.g. Délye et al. 2013). On the other hand, this patchy tradition of biological collecting has come at a cost to easily comparing organisms across large geographic regions or across temporal spans. For example, evolutionary biology would benefit from being able to analyze more common species represented in collections worldwide, because this would allow assessing phenotypic variation at much broader scales. In addition, assumptions about species ID based on morphology may be falsified by DNA data (DeSalle et al. 2005) - but also the reverse - revealing an unexpectedly high level of cryptic diversity in certain groups (e.g., Hebert et al., 2004).

Increasingly, growth of museum collections is the result of their increased relevance for ecological studies, in addition to input from taxonomically-focused collecting activities, linked to specific inventories and research projects. Whereas museum staff and associated researchers and students still undertake expeditions to increase collections and make them available for future 
325

326

327

328

329

330

331

332

333

334

335

336

337

338

339

340

341

342

343

344

345

346

347

generations, some collections also now come from large scale ecological studies (e.g. NEON in the US), although they are often conducted and archived in ways that maximize specimen value (Cook et al., 2016). Still, such systematic collecting raises the issue of what mandates should guide biological collections growth in the future. One such mandate would require a concerted effort of museums globally to collect and archive specimens in a coordinated manner that would help document current biodiversity and variation of common species across the globe. Such an effort was originally planned to be conducted by NEON in the United States, but in some cases has fallen short of this goal (Cook et al., 2016). Other ventures include the above-mentioned BOLD (with iBOL extending its coverage) which holds 6.6M DNA barcode records across 0.29M species, many of which are commonly-occurring and for a large part with vouchers present/documented. Future collections should continue to expand with specimens sampled widely across biodiversity, but in addition should amass commonly-occurring species, which can serve as environmental monitors, especially when sufficient metadata is also collected.

\section{Place-based discovery: different specimen data sets connecting to a location}

When collecting efforts from the perspective of different clades have focussed on a particular location, an additional layer of comparative information emerges, that of species-correlations, environment and edaphic correlations, and the evolution of communities i.e. the full-suite of local biodiversity. Taking 'place' into account enables asking different kind of questions and can lead to 'place-based discovery'. As Miller (2007) puts it, "Places are not simply a semantic convenience. They are a meaningful lens for viewing the world because it is orderly with respect to geographic space." As such, 'place-based' approaches in general focus on the characteristics and meaning of particular places as a fundamental starting point for a particular development or 
348 project. Especially in charity and community development work, place-based approaches aim at 349 "giving power to the community in guiding systemic change" and therefore "being recognised as 350 critical to responding effectively to certain community challenges" (www.qcoss.org.au/). In 351 education, place-based approaches are thought to "identify, recover and increase the values of

352

353

354

355

356

357

358

359

360

361

362

363

local cultural specificities" (Monardo, 2018). Analytically, place-based approaches were successfully applied in a study on community-membership predictions (Caughlin et al. 2013). In marine resources management place-based approaches, including human activities and use along with biodiversity conservation have proven important since long (Carollo et al. 2009).

Place-based learning and education is well developed (Gruenewald and Smith, 2014) and provides a context for local understanding and societal change. Natural history museums are well suited for hosting place-based activities, as well as making direct links between collections and associated data and societal activities and needs. The developing Island Digital Ecosystem Avatar (IDEA) project is one example (Davies et al., 2016), entailing "a systems ecology open science initiative to conduct the basic scientific research needed to build use-oriented simulations (avatars) of entire social-ecological systems." Many specimens will have been collected and stored, for instance for DNA barcode reference libraries, for making this possible.

For biological collections and their associated and ensuing process of discovery, the place-based approach is relevant as it seeks to understand how local information and processes are interconnected with those at a larger scale. Best practices for biological collections include a precise geographical reference for each item, as is included in the Darwin Core (see https://dwc.tdwg.org/). When collected together, sets of items are necessarily place-based. In addition to standardised metadata directly associated with biological items (Kissling et al., 2018), many other types of information are place-based and can be collected at the same location and 
371 super-imposed on point specimen data. Examples include information about geology, ground and

372 atmospheric chemistry, and archaeology. These, and other data layers - such as from GBIF

373 (species occurrences), NCBI (DNA and amino acid sequences), Open Tree of Life (phylogenetic

374 trees), Map of Life (abundance data), TraitBase (traits), GloBI (biotic interactions), see Table 1 -

375 can be associated or combined with geographical location through a geographical information

376 system (HOLOS), integrating across diverse data types and enabling testing hypotheses

377 concerning causal impacts - the 'holistic specimen'. In a sense, this approach is comparable to

378 correlative species distribution modelling (SDM) approaches such as using Maximum Entropy

379 (MaxEnt; , Philips \& Dudik, 2008), focussing on mostly abiotic and edaphic correlates.

380

381

382

383

384

385

386

387

388

389

390

391

392

393

In addition, the place-based approach can provide a baseline for understanding changes over time (Billick et al., 2013; National Research Council, 2014). An understanding of historical processes provides a means for predicting, or forecasting, how biological systems may respond to change in the near future. For instance, Willis et al. (2008) studied how climate change may affect phenology in angiosperm species in Concord, Massachusetts. Slingsby et al. (2017) studied the interaction between fire and climate change on species diversity in the South African Cape Floristic Region, allowing modelling of future vegetation response.

In general, the additional value of place-based approach for scientific discovery includes the serendipity of collecting data over periods of change identified later, as well as the interaction of researchers sharing an interest in the same geographical location or region (Michener et al., 2009). Place-based initiatives associated with larger networks (see Table 1) can provide access and understanding to a diversity of communities, which is both democratic and allows broad participation in discovery. Examples of such initiatives include developing new natural history museums (Darwin Initiative, www.darwininitiative.org.uk) and establishing a reference DNA 
394 barcode library (with vouchers for each specimen) of local biodiversity (van de Bank et al.,

395 2008; Janzen \& Hallwachs, 2016) representing a place- (not clade-)based, regional, effort. In

396 addition to natural history museums, the benefits of a place-based approach are also shared with

397 field stations, botanical gardens, and biological reserves (National Research Council, 2014).

\section{The Global Museum}

400

401

402

403

404

405

406

407

408

409

410

411

412

413

414

415

416

By 'Global Museum', we mean the potential global community of natural history museum collections that increasingly are becoming interconnected through digitization, thereby enabling both synergy and increased power of resolution in testing (mostly) evolutionary biological hypotheses. With the Global Museum, scientists worldwide are able to study and sample each other's specimens (including from remote collections), perform geometric morphometric analyses of shapes or generate high-resolution CT data and compare related images. Phenomic (and extended specimen) data on particular populations, species or actual specimens would be available at a large scale, from databases either as part of or outside the Global Museum, enabling correlation and modelling studies at a global scale, and testing evolutionary hypotheses with unprecedented power. As indicated above, many museums serve regional communities, and collections in such institutions usually reflect regional interests, fauna and flora, funding and research questions. Given that science is an international endeavour, the question can be asked as to whether evolutionary biology would be better served by enhanced ability to document and analyse patterns across regions, such as with the use of GBIF. For instance, for taxonomy, having the virtual, global, workbench of the Barcode Of Life Database BOLD (www.boldsystems.org; Ratnasingham \& Hebert, 2007) theoretically allows taxonomists globally to harmonise species delineations by collectively analyzing and interpreting DNA 
417 barcode (and associated distributional) patterns from global rather than regional data sets.

418 Boufahja et al. (2015) present another interesting example of connecting regional and global 419 scale in marine nematodes.

420

421

Museum communities are increasingly not confined by a single, local physical space but able to distribute their reach through innovations in technology. Databases and other online tools enable international access and an array of novel platforms facilitate participation of a broad swath of the public in discovery and documentation, from undergraduate classes to young children participating in aspects of the scientific process. Examples of such activities include encouraging children to make observations of butterflies in drawers, thereby likely building their sense of biodiversity. Another example is citizen science projects in which volunteers help in interpreting and digitizing information on old collection labels, as has been done for the Paris Herbarium (http://lesherbonautes.mnhn.fr/) and for brachiopod fossils at the Swedish Museum of Natural History (see Box 1).

From a Global Museum perspective, we may ask whether phenomena such as global change have been effectively documented in collections in the past so that we can use the ensemble of past collections to forecast future conditions. For instance, collections can help scientists document how $\mathrm{C} 4$ photosynthesizing plants have spread during recent decades as a response to the global increase in atmospheric CO2 concentration (Besnard et al., 2014), or how species extinctions may be overrepresented in particular clades or areas (e.g., Ricklefs, 2006). Such work would be impossible without having the integrated, properly digitised and databased platform that a Global Museum provides.

Large international data sharing initiatives (e.g. LifeWatch ERIC, GBIF, Encyclopedia of Life, BOLD and iBOL, see Table 1) allow access to collections by scientists and the public living far 
440 from privileged historic western centres for inquiry. For instance, GBIF alone provides access to

441 now over a billion records of specimens and observations from around the world. iDigBio,

442 GBIF, and the Atlas of Living Australia (ALA) and its affiliated atlases are the world's largest

443 and best-developed biodiversity data aggregators and mobilizers. As outlined above, DiSSCo is a

444 developing initiative of major significance that will unify natural science collections in Europe.

445 With increasingly distributed access to large datasets and online portals to large-scale

446 computational resources, analysis of the "big data" of biodiversity records can also go global

447 (see Antonelli et al. (2015) for an example in global angiosperm biogeography and speciation).

448 Digitization of collections will be increasingly important in this respect; there are many valuable

449 but undigitized collections (and literature resources) residing in museums, not in the least outside

450 of developed countries.

But a Global Museum is more than increasingly inter-connected biodiversity databases across the

452 globe. In order to be effective and truly innovative it should be synergistic in answering scientific

453

454

455

456

457

458

459

460

461

462 questions, in a way that single museum collections cannot do. For instance, linking data on

phenomes, including genomes, proteomes, parasites, secondary metabolite chemistry,

distributions, morphology and generally all ‘extended specimen' metadata, across global

museum specimen collections would enable testing new hypotheses and correlations, and with

synergy not unlike that observed in studies using synthesis radio telescopes (Levanda and

Leshem 2010). Exciting examples of such studies can already be found for instance in

Lamichhaney \& al. (2019) where the authors focussed on phenotypical convergence and its possible genomic correlations.

For a synergistic Global Museum to happen across a wide spectrum of museum situations and funding sources, there would need to be ample coordination in terms of setting-up an operational 
463 infrastructure, governance structure and data standards. Issues such as data ownership visibility 464 and transparency could perhaps be improved using the above-mentioned emerging blockchain 465 technologies. The level of funding required for such an initiative, and what balance between 466 national and global funding is preferred and over what time frame, are questions that need to be

467

468

469

470

471

472

473

474

475

476

477

478

479

480

481

482

483

484

485

explored, probably by museum communities and federal funding agencies. Additionally, how

will policy makers as well as the general public be convinced of the importance of a Global

Museum as a top-priority? Comparisons are often made with astrophysicists and how they are

able, as a united community, to leverage unprecedented large sums of funding for ever more

'extremely' and 'overwhelmingly' large instrumentations (see

https://en.wikipedia.org/wiki/Overwhelmingly_Large_Telescope). How can global biodiversity

scientists and museums achieve comparable goals? What role can existing platforms and

museums play already? The best roadmap to follow towards a Global Museum is beyond the

scope of this paper, but we do appreciate the reality of selling the concept to 'the public' may be a formidable challenge.

\section{Increasing the relevance of museums through digitization and imaging}

As indicated above, digitization of collections is important for achieving a global perspective on (big) biodiversity data. To facilitate the coordination of collection and databasing efforts between museums - a necessity to achieve a Global Museum - it is vital to increase awareness of what knowledge is available, not only at regional museums but across museums globally. This is most easily achievable through digitization of the collections. Moreover, such digitization also opens up the collections for a number of additional researchers interested in overall temporal or spatial patterns in biodiversity. iDigBio (see above) provides a good example of how digitization can be 
486

487

488

489

490

491

492

493

494

495

496

497

498

499

500

501

502

503

504

505

506

507

508

successful and provides outreach to a global user base. In its first 10 years, iDigBio and NSF

have appropriately prioritized digitization of specimens that can drive collaborative research and answer specific biological questions. However, this specialization necessarily results in only a small fraction of available specimens being digitized.

For any information system to be successful, proper nomenclature and taxonomy of specimens involved are paramount, the bedrock of success. Names applied to specimens will change as science progresses but data will remain. Ideally, names applied to specimens are up-to-date but good museums do indeed worry about synonymy. A prime example of combining data bases and 'vetting' them is VertNet (Constable et al., 2010) which combines four global vertebrate networks: Mammal Networked Information System (MaNIS), Ornithological Information System (ORNIS), HerpNET and FishNet 2. These networks collectively mobilize over 52 million records from more than 70 institutions, representing about $70 \%$ of all the vertebrate species occurrence data that are accessible through GBIF. A good example for keeping track of synonyms is the Swedish Taxonomic Database DynTaxa (https://www.dyntaxa.se/), and for combining Biodiversity data bases see the Swedish LifeWatch Analysis Portal (https://www.analysisportal.se/).

A major question for the future is how the community should greatly expand the scope of digitized specimens. In the US, the Biodiversity Collections Network (BCoN) developed a strategy for the next decade to "maximize the value of our collections resource for research and education" envisaging building a network of Extended Specimen data (BCoN 2018; Webster, 2017; see also BCoN 2019). Just as incidentally collected historical specimens often prove useful for research questions not envisioned during the collecting event, it is also likely that specimens digitized without a specific research question in mind will prove useful for answering scientific 
509 or societal questions, especially if digitized on a large scale. But digitizing 'blindly' must of

510 course be balanced with the pressure of meagre resources; enabling citizen scientists to assist

511 offers a good solution (Rouhan et al., 2016). Large amounts of metadata remain to be digitized

512 and would generate knowledge on biogeography (geographic data of specimens), disease spread

513 (genetic material from parasites), biological interactions (pollination data), phenology, or shifts

514 in species distributions (Suarez \& Tsutsui, 2004; James \& al., 2018). New advances in image

515 recognition through deep learning using neural networks are also likely to enable easy

516 identification of many species, such as already implemented in the iNaturalist platform, and

517 hence help digitization.

518 Tracking specimen taxonomy. For research on temporal patterns of global change, such as global

519 warming studies or analyses of movement of hybrid zones, museum records provide a unique

520 source of historical records. Because they are backed up by physical specimens, records can be

521 identified to individual species irrespective of how many taxonomic changes have occurred since

522 specimen collection, an endeavour that is often impossible if the records were purely

523 observational. However, an important caveat of this effort is that it is rarely obvious from online

524 databases on what taxonomical opinion each identification was based. Indeed, to capitalize on

525 the inherent strength of specimen-based records a citation to the taxonomic revision behind each

526 identification would be ideal, but is not always available. The above-mentioned BCoN (2018)

527 report suggests exploring blockchain technology (https:/en.wikipedia.org/wiki/Blockchain;

528 Iansiti \& Lakhani, 2017), which is a decentralized approach to data exchange that has already

529 gained significant traction in the corporate, academic, and federal arenas and is applied to track

530 items through complex supply chains. Blockchain technology involves an open, distributed

531 ledger, or list of cryptographically linked records ('blocks'), that can record transactions between 
532 two parties efficiently and in a verifiable and permanent way (Iansiti \& Lakhani, 2017). It is

533 considered to enable decentralised 'incorruptible repositories of quality graded data' (Hilsberg et

534 al., 2018) and BCoN (2018) expects it may provide "viable solutions for how data and products

535 can be stored, linked and shared with collaborators and stakeholders, facilitating transparency

536 and traceability. In addition, it is expected that it could be valuable for low-cost data-preservation

537 (while enhancing data-reachability) as well as enhancing collection management (see also

538 Hilsberg et al., 2018).

539 Combining specimen databases. Another challenge related to digitization and to the value of the 540 physical specimens is that specimens may be one of the only clear, if frequently underutilized, 541 ways to identify duplicates between different databases. For example, this challenge is often 542 encountered among mammalian fossils where several databases, including 'New and Old World 543 Mammals' (NOW) and 'PaleoDB', have been started independently. Together these databases 544 completely document diversity for some groups, and out of $\sim 1586$ accepted species of carnivores 545 and relatives (Carnivora, Hyanodonta and Oxyaenidae) in the fossil record, 1460 species are 546 included in at least one of them (Faurby et al. 2019). However, individually they are each highly 547 incomplete (1121 species, 6385 records in NOW, 1040 species (6756 records) in PaleoDB). 548 Analyses attempting to summarize the complete fossil record therefore needs to combine 549 databases. For many uses, such as when estimating speciation or extinction rates (Silvestro \& al., 550 2014), it would be highly desirable to resolve redundancy between databases, a challenging 551 effort that could be made trivial if both databases contained the museum specimen ids for the 552 records.

553 Big clades, large collections. Digitization will be extremely challenging for the most diverse 554 taxonomic groups, such as typically large collections of insects, although there have been 
555 attempts to automate digitization of such groups (Hudson \& al., 2015). Generally, though, a lack

556 of professional staff, infrastructure and facile technology are usually limiting this process. For

557 example, a competition sponsored by NSF with US \$1M (see

558 https://www.nsf.gov/news/news_summ.jsp?cntn_id=133377) as an award for developing

559 technology to automate the digitization of insect specimens and metadata (often from hand-

560 written specimen tags) failed to identify a winner because the proposals from all competing

561 teams fell short of award criteria. For any specimen collection, knowing its limits, in

562 geographical and temporal distribution and in size, especially for the most common groups, may

563 suffice for further scientific analysis (see https://www.analysisportal.se). Finer scale

564 distributional data in such cases can easily be supplemented by citizen science initiatives (e.g

565 iNaturalist), especially if associated with pictures or movies with smartphones that contain

566 georeferenced and timestamped records that facilitate re-validation through inspection of the

567 images by experts (see for instance iSpot; Silvertown et al., 2015 and Beespotter

568 https://beespotter.org).

569 Museums still harbour large amounts of undiscovered and undocumented information. The total 570 number of specimens deposited in museum collections around the world may be as large as 1-2

571 billion (Ariño, 2010), and for herbaria an estimated $350 \mathrm{M}$ specimens are known to be deposited

572 in 3400 collections world-wide (Soltis, 2007). Moreover, statistical approaches to estimate the

573 size of collections agreed in 2010 that less than 5\% of the universe of natural history collections

574 data is available in databases such as GBIF (Ariño, 2010), although this fraction has been

575 decreasing, with the fast increase of observation data in GBIF (see above and Troudet et al.,

576 2018). Wilson (2003) noted that the smaller the organism the more poorly known the group to

577 which it belongs, exemplified by fungi, nematodes and microbes. For instance, a random 
578 selection of specimens collected in a tropical rain forest and deposited in jars at a natural history

579 collection resulted in the description of almost 200 new species of ichneumonid parasitoid wasps

580 to science (Veijalainen et al., 2012). Bebber et al. (2010) described a comparable case for

581 angiosperm species, with an estimated 35,000 undescribed species already residing in herbarium

582 collections. An abundance of undescribed species is only the tip of the iceberg on the amount of

583 data undiscovered and undocumented in the world's museums. Again, enough professional staff

584 and infrastructure is needed to tackle this problem.

585 In terms of species diversity, and in addition to the hard curation work by thousands of

586

587

588

589

590

591

592

593

594

595

596

597

598

599 taxonomists, DNA barcoding reference libraries such as BOLD (Ratnasingham \& Hebert, 2007)

and UNITE (Koljag \& al., 2013) could provide a framework against which the extent of diversity deposited at natural history collections can be measured, using DNA barcodes as quick ID tool in cases where specimens may be hard to identify. For instance, for associating ana- and telomorphs in macrofungi such quick ID can be essential. However, molecular approaches to identify hidden diversity remain debatable (e.g., Brower, 2006) but can be overcome in large clades such as Lepidoptera (Hebert et al., 2010). In UNITE fungal species hypotheses are generated and named, but also tagged with a citable digital object identifiers (DOIs). This allows unambiguous communication, and harmonisation of species concepts throughout communities. In comparison, BOLD allows barcode index numbers (BINs) to refer to barcode clusters that have not been yet described taxonomically.

Programs like the UK Darwin Initiative train observers and scientists in countries rich in diversity but low in funding for conservation and science surveys. These programs can further support democratization of not just specimens and data but also the knowledge for performing 
600

601

602

603

604

605

606

607

608

609

610

611

612

613

614

615

616

617

618

619

620

621

analyses and conducting research. However, much more needs to be done in this area, especially in capacity building, infrastructural development, and task distribution.

Reference collections. A major need for collections worldwide is to develop basic molecular data associated with a given taxon, but possibly genomes, transcriptomes and phenomes too. For example, nearly all museum genetic resources collections are unsuitable for gene expression work, requiring new collection of fresh samples for this endeavour (Zhang et al. 2012). The key importance is the burgeoning use of metabarcoding in ecological studies that can be anchored to museum specimens, and thus linked to the associated metadata. Many museums have embarked on such endeavors, for example at CSIRO in Australia, and efforts of multiple museums ideally come together in clade-based DNA barcode projects in BOLD.

\section{Promoting science through museums}

To enhance the broader relevance of natural history museums it is also important to message effectively to industry and policy makers. In particular, the museum community should explore ways to use specimens to find novel ways to bridge the traditional chasm between the sciences, arts and humanities. Shared themes include place-based research and experiential learning, both encouraged in instructional efforts in science, technology, engineering and mathematics (STEM fields) and the arts. Both the arts and sciences depend on inspiration, creativity, and critical assessment, and museum specimens serve well as sources for both inspiration and fascination. (The 'Hall of Biodiversity' at Porto’s Botanical Garden and Natural History Museum (MHNC), may serve as a prime example; see https://mhnc.up.pt/galeria-da-biodiversidade/). While scientific education and research offer rigorous methods for testing hypotheses and creating new 
622 knowledge, integration of experiential art and humanities into science fosters non-traditional

623 ways of exploring and messaging about our world (Balengee 2010). Natural history museums

624 should continue their efforts to train scientists and artists to develop novel solutions to emerging

625 problems, especially as we face an increasingly uncertain environmental future.

626

627

628

629

630

631

632

633

634

635

636

637

638

639

640

641

642

643

Efforts by a Global Museum to assemble collections that will fulfil their key roles in the future require facilitating international agreement and participation. Such a massive effort cannot remain the province of a relatively few marginally resourced programs. Identifying the answers to the most pressing questions facing society and our environment require fertile spaces for cultivating innovation in the context of training in knowledge of biodiversity. This task is impossible without museum spaces and collection resources. We cannot afford to 'waste' the potential of natural specimens due to degradation, improper storage, or disposal, especially in the light of rapid biodiversity loss. They need space-efficient, climate-controlled and pest-free spaces. Innovations in these areas are likely needed to accommodate collections in the long term (hundreds to thousands of years) and to deal with preservation issues that may be exacerbated by global climate change (including increasing frequency of extreme weathers, hurricanes, flooding). Museum networks need to be global and there have to be initiatives and strategies developed to support and improve facilities throughout the world (see also Table 1).

\section{Public perception of natural history museums}

We argue that natural history museums should be regarded as 'Innovation Incubators', places where 'anti-disciplinary' science is thriving by building bridges between otherwise or so far improbable disciplines, and scientists from various 'disciplines' meet, an Academic Nexus of 
644 Integration. Because natural history collections can facilitate examining diverse aspects of 645 taxonomic, morphological, genetic, and chemical variation across vast temporal and spatial 646 scales, they can help diverse scientists bridge the gaps between traditional disciplines. In places 647 where this situation is not yet in place the way to get there would be to enable ready access to 648 both collections and research facilities, an effort that has been highly successful, for example, 649 under the European SYNTHESYS Access scheme for the last decade. The K-12 education 650 project "Exploring California Biodiversity" at the University of California, Berkeley 651 (http://gk12calbio.berkeley.edu; Mitchell \& Gillespie, 2007), which takes grade school students 652 and teachers into the field, provides an excellent example of natural history museum collections 653 broadening access and opportunities for education. Efforts such as AIM-UP! and its successor 654 Biodiversity Literacy in Undergraduate Education (BLUE:

655 https://www.biodiversityliteracy.com/) have combined the expertise of educators, curators, 656 collection managers, database managers, and others in undergraduate education (Cook et al., 657 2016; Lacey et al., 2017).

658 In terms of public perception of natural history museums, it is important to safeguard their role in 659 society and justify long-term funding by continuing outreach and engaging the general public by proper messaging, for instance by initiating citizen science projects. Above, we outlined how issues regarding the justification of specimen collecting do not seem to be resolved within a vocal minority of the general public. Clearly, museum curators and scientists need to join forces

663 in working proactively with the public to increase their awareness of, and appreciation for, the 664 practice of rigorous biological sampling (see also Rocha et al. 2014). 
666 Collecting for the future: integrated analysis of museum specimens for evolutionary 667 biology

668 Museums need room to grow in targeted ways that will allow us to address scientific issues 669 critical to looming societal issues such as emerging pathogens and food security (Morrison et al., 670 2017; Schindel \& Cook, 2018) (see Box 2). Specimen-based field work should aim to preserve 671 extensive sets of natural history material at a particular time and place that would represent

672

673

674

675

676

677

678

679

680

681

682

683

684

685

686

687

688

multiple individuals of each species, multiple species per collecting locale, and multiple diverse aspects of individual specimens. For example, collection of mammals and their associated ectoparasites and digestive tracts has led to detailed understanding of co-evolution of hosts and parasites (Cook et al,. 2017) and can fuel future studies of the role of the microbiome in such processes (Roggenbuck et al., 2014, Greiman et al., 2018). Such holistic collection events can better capture the complex interactions of biotic communities and, if repeated, over time could provide key insights into changing conditions. Additionally, as mentioned above, focused, calibrated collecting of a subset of common, widespread species are necessary to provide baselines for studies of organismal response to global change. The recent attempt to estimate population numbers of North American Monarch Butterflies (Danaus plexippus) from museum collections (Boyle et al. 2019) met with some controversy, in part because there are clear biases and variation in collecting effort across years for this species, as well as their host plants (Ries et al. 2019; Wepprich 2019). Discussions should be held that address how we can best leverage collecting activities across the Global Museum and that planning should lead to a global effort to more rigorously inventory biodiversity.

\section{Conclusions}


689 For hundreds of years, natural history museums around the world have provided the general 690 public and scientists with numerous opportunities to learn more about our natural world. Taken 691 together, this 'Global Museum' must be seen as one of the most valuable assets of modern 692 society and culture, providing the material to address challenges facing humanity today - such as

693 694 695 696 697 698

baseline information against which to test hypotheses of local and global environmental change and a critical regional cultural touchstone for the public. Natural history museums, as Academic Nexes of Integration, can function as inter-disciplinary meeting places, or innovation incubators, where questions are addressed that we did not consider asking before. The core of these institutions are the specimens. To maximise their use, it is therefore imperative to carefully consider how to best sample, preserve, handle, and store specimens in ways that not only meet today's demands but also new, unforeseen needs. Viewing natural history museums as critical infrastructure for scientific inquiry and public understanding may help raise their profile and awareness, facilitating continued support.

\section{Acknowledgements}

The paper is the result of a three-day workshop on 'The role of museums in modern evolutionary biology’ organized by Chalmers University of Technology and the University of Gothenburg (Sweden), under the auspices of the Gothenburg Centre for Advanced Studies (GoCAS), and held 7-9 June, 2017. Participants from Europe, the United States, South Africa and Peru were primarily based at natural history museums and botanical gardens as researchers or administrators and were chosen to represent diverse areas of museum-based science. 
710 We are very thankful to Karin Hårding, Gunnar Nyman, and Mattias Marklund for their 711 continuous support and assistance in the program as GoCAS organizers.

712

713 Funding

714 We acknowledge funding from the following sources: the Swedish Research Council

715 (B0569601), the European Research Council under the European Union's Seventh Framework

716 Programme (FP/2007-2013, ERC Grant Agreement 331024), the Swedish Foundation for

717 Strategic Research, a Wallenberg Academy Fellowship, the Faculty of Sciences at the University

718 of Gothenburg, the Wenner-Gren Foundations, and the David Rockefeller Center for Latin

719 American Studies at Harvard University to A.A.; the Marie Sklodowska-Curie research

720 fellowship (European Commission, project MARIPOSAS-704035) to P.M.-M. 


\section{$723 \quad$ Figure legends}

724 Figure 1. The centrality of natural history collections to evolutionary biology and public

725 understanding. Users, contributors and stakeholders of natural history collections are indicated;

726 yellow arrows represent data flow, green arrows the flow of specimens.

727

728 
730

731

732

733

734

735

736

737

738

739

740

741

742

743

744

745

746

747

748

749

750

751

752

753

754

755

756

\section{References}

Alivisatos AP, Blaser MJ, Brodie EL, Chun M, Dangl JL, Donohue TJ, Dorrestein PC, Gilbert JA, Green JL, Jansson JK, Knight R, Maxon ME, McFall-Ngai MJ, Miller JF, Pollard KS, Ruby EG, Taha SA, Unified Microbiome Initiative Consortium. 2015. A unified initiative to harness Earth's microbiomes. Science 350:507-508 DOI: 10.1126/science.aac8480.

Andreone F, Bartolozzi L, Boano G, Boero F, Bologna MA, Bon M, Bressi N, Capula M, Casale A, Casiraghi M, Chiozzi G, Delfino M, Doria G, Durante A, Ferrari M, Gippoliti S, Lanzinger M, Latella L, Maio N, Marangoni C, Mazzotti S, Minelli A, Muscio G, Nicolosi P, Pievani T, Razzetti E, Sabella G, Valle M, Vomero V, Zilli A. 2014. Italian natural history museums on the verge of collapse? ZooKeys 456: 139-146. doi: 10.3897/zookeys.456.8862

Ariño AH. 2010. Approaches to estimating the universe of natural history collections data. Biodiversity Informatics 7:81-92.

Bakker FT. 2015. DNA sequences from plant herbarium tissue. In: Hörandl E, Appelhans M, eds. Next-generation sequencing in plant systematics, p271-284. International Association for Plant Taxonomy (IAPT)

Bakker FT, Lei D, Yu J, Mohammadin S, Wei Z, Van de Kerke S, Gravendeel B, Nieuwenhuis M, Staats M, Alquezar-Planas DE, Holmer R. 2016. Herbarium genomics: Plastome sequence assembly from a range of herbarium specimens using an terative organelle genome assembly (IOGA) pipeline. Biological Journal of the Linnean Society. 117:33-43 http://dx.doi.org/10.1111/bij.12642.

Balengee, B. 2010. Malamp, the occurrence of deformities in amphibians, Arts Catalyst, London and Yorkshire Sculpture Park, Wakefield, England.

Bank M van de, Olivier M, Duthoit S, Savolainen V. 2008. A DNA barcode for the flora of the Kruger National Park (South Africa). South African Journal of Botany 74:370-371, 10.1016/j.sajb.2008.01.073.

Bebber DP, Carine MA, Wood JRI, Wortley AH, Harris DJ, Prance GT, Davidse G, Paige J, Pennington TD, Robson NKB, Scotland RW. 2010. Herbaria are a major frontier for species discovery. Proceedings of the National Academy of Sciences of the United States of America 107:22169-22171.

Berenbaum MR and A. Zan. 1998. Chemical phenotype matching between a plant and its insect herbivore. Proceedings of the National Academy of Sciences of the United States of America 95: 13743-13748. 
Besnard G, Christin P-A, Malé P-JG, L'huillier E, Lauzeral C, Coissac E, Vorontsova MS. 2014. From museums to genomics: old herbarium specimens shed light on a C3 to C4 transition. Journal of Experimental Botany 65:6711-6721, doi 10.1093/jxb/eru395

Bi K, Linderoth T, Vanderpool D, Good JM, Nielsen R, Moritz C. 2013. Unlocking the vault: next-generation museum population genomics. Molecular Ecology 22:6018-6032.

Biodiversity Collections Network. 2018. Extending U.S. Biodiversity Collections to Promote Research and Education. https://www.idigbio.org/content/biodiversity-collections-network-releases-new-report-extending-us$\underline{\text { biodiversity-collections }}$

Biodiversity Collections Network. 2019. Extending U.S. Biodiversity Collections to Promote Research and Education. American Institute of Biological Sciences, Washington, DC, 8 pp

Bolotov IN, Makhrov AA, Yu M, Gofarov, Aksenova OV, Aspholm PE, Bespalaya YV, Kabakov MB, Kolosova YS, Kondakov AV, Ofenböck T, Ostrovsky AN, Yu Popov I, von Proschwitz T, Rudzīte M, Rudzītis M, Sokolova SE, Valovirta I, Vikhrev IV, Vinarski MV, Zotin AA. 2018. Climate Warming as a Possible Trigger of Keystone Mussel Population Decline in Oligotrophic Rivers at the Continental Scale. Scientific Reports 8:35, doi:10.1038/s41598-017-18873-y

Boufahja F, Semprucci F, Beyrem H, Bhadury P. 2015. Marine Nematode Taxonomy in Africa: Promising Prospects Against Scarcity of Information. J Nematol 47(3): 198--206

Boyle JH, Dalgleish HJ, Puzey JR. 2019. Monarch butterfly and milkweed declines substantially predate the use of genetically modified crops. Proceedings of the National Academy of Sciences of the United States of America 116: 3006-3011, https://www.pnas.org/cgi/doi/10.1073/pnas.1811437116

Brower AVZ. 2006. Problems with DNA barcodes for species delimitation: “Ten species" of Astraptes fulgerator reassessed (Lepidoptera: Hesperiidae). Systematics and Biodiversity 4:127-132

Billick I, Babb I, Kloeppel B, Leong JC, Hodder J, Sanders J, Swain H. 2013. Field Stations and Marine Laboratories of the Future: A Strategic Vision. National Association of Marine Laboratories and Organization of Biological Field Stations. Available at http://www.obfs.org/fsml-future

Colegate SM, Welsh SL, Gardner DR, Betz JM, Panter KE. 2014. Profiling of Dehydropyrrolizidine Alkaloids and their N-Oxides in Herbarium-Preserved Specimens of Amsinckia Species Using HPLC-esi(+)MS. J Agric Food Chem. 62(30):7382-7392. 
Constable H, Guralnick R, Wieczorek J, Spencer C, Peterson AT. 2010. VertNet: A New Model for Biodiversity Data Sharing. PLoS Biol 8(2): e1000309, doi:10.1371/journal.pbio.1000309.

Cook JA, Edwards SV, Lacey EA, Guralnick RP, Soltis PS, Soltis DE, Welch CK, Bell KC, Galbreath KE, Himes C, Allen JM, Heath TA, Carnaval AC, Cooper KL, Liu M, Hanken J, Ickert-Bond S. 2014. Natural History Collections as Emerging Resources for Innovative Education. BioScience 64:725-734.

Cook JA, Galbreath KE, Bell KC, Campbell ML, Carrière S, Colella JP, Dawson NG, Dunnum JL, Eckerlin RP, Greiman SE, Fedorov V, Hass GMS, Haukisalmi V, Henttonen H, Hope AG, Jackson D, Jung T, Koehler AV, Kinsella M, Krejsa D, Kutz SJ, Liphardt S, MacDonald SO, Malaney JL, Makarikov A, Martin J, McLean BS, Mulders R, Nyamsuren B, Talbot SL, Tkach VV, Tsvetkova A, Toman HM, Waltari EC, Whitman JL, Hoberg EP. 2017. The Beringian Coevolution Project: Holistic Collections of Mammals and Associated Parasites Reveal Novel Perspectives on Evolutionary and Environmental Change in the North. Arctic Science 3:585-617.

Cook JA, Greiman S, Agosta RP, Anderson BS, Arbogast RJ, Baker W, Boeger RD, Bradley DR, Brooks R, Cole JR, Demboski AP, Dobson JL, Dunnum RP, Eckerlin J, Esselstyn K, Galbreath J, Hawdon H, Hoekstra S, Kutz J, Light L, Olson BD, Patterson JL, Patton AJ, Phillips E, Rickart DS, Rogers M, Siddall V, Tkach VV, Hoberg EP. 2016. Transformational principles for NEON sampling of mammalian parasites and pathogens: a response to Springer and colleagues. BioScience 66:917-919.

Cook JA, Lacey EA, Ickert-Bond SM, Hoberg EP, Galbreath KE, Bell KC, Greiman SE, McLean BS, Edwards SV. 2016. From Museum Cases to the Classroom: Emerging Opportunities for Specimen-Based Education. Pp 787-799 in Pavlinov I, ed. “Aspects of Biodiversity”, Volume 54, Archives of Zoological Museum of Moscow State University, Moscow, Russia.

Darwin Initiative, https://www.gov.uk/government/groups/the-darwin-initiative

Davies N, Field D, Gavaghan D, Holbrook SJ, Planes S, Troyer M, Bonsall M, Claudet J, Roderick G, Schmitt RJ. 2016. Simulating social-ecological systems: the Island Digital Ecosystem Avatars (IDEA) consortium. GigaScience 5, 1. http://doi.org/10.1186/s13742-016-0118-5.

Délye C, Deulvot C, Chauvel B. 2013. DNA Analysis of Herbarium Specimens of the Grass Weed Alopecurus myosuroides Reveals Herbicide Resistance Pre-Dated Herbicides. PLoS ONE 8(10), e75117. 
812

813

814

815

816

817

818

819

820

821

822

823

824

825

826

827

828

829

830

831

832

833

834

835

836

Droege G, Barker K, Seberg O, Coddington J, Benson E, Berendsohn WG, Bunk B, Butler C, Cawsey EM, Deck J, Döring M, Flemons P, Gemeinholzer B, Güntsch A, Hollowell T, Kelbert P, Kostadinov I, Kottmann R, Lawlor RT, Lyal C, Mackenzie-Dodds J, Meyer C, Mulcahy D, Nussbeck SY, Ó Tuama É, Orrell T, Petersen G, Robertson T, Söhngen C, Whitacre J, Wieczorek J, Yilmaz P, Zetzsche H, Zhang Y, Zhou X. 2016. The Global Genome Biodiversity Network (GGBN) Data Standard specification. Database. baw125, doi: -10.1093/database/baw125.

Dunnum JL, Yanagihara R, Johnson KM, Armien B, Batsaikhan N, Morgan L, Cook JA. 2017. Biospecimen repositories and integrated databases as critical infrastructure for pathogen discovery and pathobiology research. PloS Neglected Tropical Diseases 11: e0005133.

Faurby S, Werdelin L, Antonelli A. 2019. Dispersal ability predicts evolutionary success among mammalian carnivores. bioXrev preprint, doi: http://dx.doi.org/10.1101/755207

Foley, 2015. the_Macroscope.org

Gitzendanner MA, PS Soltis, GK-S Wong, BR Ruhfel, Soltis DE. 2018. Plastid phylogenomic analysis of green plants: A billion years of evolutionary history. American Journal of Botany 105(3): 291-301, doi:10.1002/ajb2.1048.

Gokhman D, Lavi E, Prüfer K, Fraga MF, Riancho JA, Kelso J, Pääbo S, Meshorer E, Carmel L. 2014. Reconstructing the DNA Methylation Maps of the Neandertal and the Denisovan. Science 344:523-527, doi: $10.1126 /$ science. 1250368 .

Graham CH, Ferrier S, Huettman F, Moritz C, Peterson AT. 2004. New developments in museum-based informatics and applications in biodiversity analysis. Trends in Ecology \& Evolution 19(9):497-503.

Grayson P, Sin SYW, Sackton TB, Edwards SV. 2017. Comparative genomics as a foundation for evo-devo studies in birds, Pages 11-46 in G. Shen, ed. Methods in Molecular Biology: Avian and Reptilian Developmental Biology. New York, Humana Press.

Gruenewald, D.A. and Smith, G.A. eds. 2014. Place-based education in the global age: Local diversity. Taylor and Francis Press, New York. 
Greiman, S., J. A. Cook, V. V. Tkach, E. P Hoberg, D. Menning, A. G. Hope, S. A Sonsthagen, and S. L. Talbot. 2018. Museum metabarcoding: a novel method revealing gut helminth communities of small mammals across space and time. International Journal of Parasitology 48:1061-1070.

Hart ML, Forrest LL, Nicholls JA \& CA Kidner. 2016. Retrieval of hundreds of nuclear loci from herbarium specimens. Taxon 65(5): 1081-1092.

Hebert PDN, Penton EH, Burns JM, Janzen DH, Hallwachs W. 2004. Ten species in one: DNA barcoding reveals cryptic species in the neotropical skipper butterfly Astraptes fulgerator. Proceedings of the National Academy of Sciences of the United States of America 101: 14812-14817.

Hebert PDN, deWaard JR, Landry J-F. 2010. DNA barcodes for 1/1000 of the animal kingdom. Biol. Lett. (2010) 6, 359-362 doi:10.1098/rsbl.2009.0848

Hess CM, Wang Z, and SV Edwards. 2007. Evolutionary genetics of Carpodacus mexicanus, a recently colonized host of a bacterial pathogen, Mycoplasma gallisepticum. Genetica 129:217-225.

Hilsberg, T., Robinson, A., Robinson, M., Haynes, D. 2018. Biocoin.Life Foundation. White Paper V0.85. https://static1.squarespace.com/static/5a338858d7bdcea6d17ccc0f/t/5a7f8d45652deaf340ccdd98/15183086789 28/White+Paper+-+Developing+a+Global+Biocoin.life+20180211.pdf

Hofreiter M, Paijmans JLA, Goodchild H, Speller CF, Barlow A, Fortes GG, Thomas JA, Ludwig A, Collins MJ. 2015. The future of ancient DNA: Technical advances and conceptual shifts. BioEssays 37: 284-293, doi: 10.1002/bies.201400160

Holmes MW, Hammond TT, Wogan GOU, Walsh RE, LaBarbera K, Wommack EA, Martins FM, Crawford JC, Mack KL, Bloch LM, MW Nachman. 2018. Natural history collections as windows on evolutionary processes. Molecular Ecology https://doi.org/10.1111/mec.13529

Holos, Ecoengine, UC Berkeley, https://holos.berkeley.edu/about/

Horn IR, Kenens Y, Palmblad NM, van der Plas-Duivesteijn SJ, Langeveld BW, Meijer HJM, Dalebout H, Marissen RJ, Fischer A, Vincent Florens FB, Niemann J, Rijsdijk KF, Schulp AS, Laros JFJ, B Gravendeel. 2019. Palaeoproteomics of bird bones for taxonomic classification. Zoological Journal of the Linnean Society 186:650-665, https://doi.org/10.1093/zoolinnean/zlz012 
Hudson LN, Blagoderov V, Heaton A, Holtzhausen P, Livermore L, Price BW, van der Walt S, Smith VS. 2015. Inselect: Automating the Digitization of Natural History Collections. https://doi.org/10.1371/journal.pone.0143402

Iansiti M; Lakhani KR. 2017. The Truth About Blockchain. Harvard Business Review. Harvard University.

IBOL (International Barcode of Life), 2014. What is iBOL? http://ibol.org/about-us/what-is-ibol/

Ingala MR, Simmons NB, Wultsch C, Krampis K, Speer KA, Perkins SL. 2018. Comparing Microbiome Sampling Methods in a Wild Mammal: Fecal and Intestinal Samples Record Different Signals of Host Ecology, Evolution. Front. Microbiol. https://doi.org/10.3389/fmicb.2018.00803

James SA, Soltis PS, Belbin L, Chapman AD, Nelson G, Paul DL, Collins M. 2018. Herbarium data: Global biodiversity and societal botanical needs for novel research. Applications in Plant Sciences. 6(2): e1024; https://doi.org/10.1002/aps3.1024

Janzen DH \& Hallwachs W. 2016. DNA barcoding the Lepidoptera inventory of a large complex tropical conserved wildland, Area de Conservacion Guanacaste, northwestern Costa Rica. Genome 59(9):641-60. doi: 10.1139/gen-2016-0005.

Jayaram K \& Full RJ. 2016. Cockroaches traverse crevices, crawl rapidly in confined spaces, and inspire a soft, legged robot. Proceedings of the National Academy of Sciences of the United States of America 113: E950E957.

Johnson KW. 2018. The Ornithologist the Internet Called a Murderer. The New York Times, June 15, 2018.

Jones CA, Daeler CC. 2018. Herbarium specimens can reveal impacts of climate change on plant phenology; a review of methods and applications. PeerJ 6:e4576 https://doi.org/10.7717/peerj.4576

Kissling WD, Ahumada JA, Bowser A, Fernandez M, Fernández N, García EA, Guralnick RP, Isaac NJB, Kelling S, Los W, McRae L, Mihoub JB, Obst M, Santamaria M, Skidmore AK, Williams KJ, Agosti D, Amariles D, Arvanitidis C, Bastin L, De Leo F, Egloff W, Elith J, Hobern D, Martin D, Pereira HM, Pesole G, Peterseil J, Saarenmaa H, Schigel D, Schmeller DS, Segata N, Turak E, Uhlir PF, Wee B, AR Hardisty. 2017. Building essential biodiversity variables (EBVs) of species distribution and abundance at a global scale. Biological Reviews 93:600 - 625, https://doi.org/10.1111/brv.12359 
889

890

891

892

893

894

895

896

897

898

899

900

901

902

903

904

905

906

907

908

909

910

911

912

913

914

915

Kõljalg U, Nilsson RH, Abarenkov K, Tedersoo L, Taylor AFS, Bahram M, Bates SB, Bruns TD, BengtssonPalme J, Callaghan TM, Douglas B, Drenkhan T, Eberhardt U, Dueñas M, Griffith TGW, Hartmann M, Kirk PM, Kohout P, Larsson E, Lindahl BD, Lücking R, Martín RMP, Matheny PB, Nguen NH, Niskanen T, Oja J, Peay KG, Peintner U, Peterson M, Põldmaa K, Saag L, Saar I, Schüssler A, Scott JA, Senés C, Smith ME, Suija A, Taylor DL, Telleria T, Weiss M, Larsson K-H, 2013. Towards a unified paradigm for sequence-based identification of fungi. Molecular Ecology 22: 5271-5277.

Lacey EA, Hammond TT, Walsh RE, Bell KC, Edwards SV, Ellwood ER, Guralnick R, Ickert-Bond SM, Mast AR, McCormack JE, Monfils AK, Soltis PS, Soltis DE, Cook JA. 2017. Climate change, collections and the classroom: using big data to tackle big problems. Evo Edu Outreach 10:2; doi 10.1186/s12052-0170065-3

Lamichhaney S, Card DC, Grayson P, Tonini JFR, Bravo GA, Näpflin K, Termignoni-Garcia F, Torres C, Burbrink F, Clarke JA, Sackton TB, and SV Edwards. 2019. Integrating natural history collections and comparative genomics to study the genetic architecture of convergent evolution. Phil. Trans. R. Soc. B 374: 20180248. http://dx.doi.org/10.1098/rstb.2018.0248

Levanda R, Leshem A. 2010. Synthetic aperture radio telescopes. IEEE Signal Processing Magazine 27(1):14 29, doi: 10.1109/MSP.2009.934719

Llamas B, Holland ML, Chen K, Cropley JE, Cooper A, Suter CM. 2012. High-Resolution Analysis of Cytosine Methylation in Ancient DNA. PLoS ONE 7, e30226 34.

Liede-Schumann S, Khanum R, Mumtaz AS, Gherghel I \& Pahlevani A. 2016. Going west - A subtropical lineage (Vincetoxicum, Apocynaceae: Asclepiadoideae) expanding into Europe. Molecular Phylogenetics and Evolution 94: 436-446.

Lindqvist C, Rajora OP (eds.). 2019. Paleogenomics, Genome-Scale Analysis of Ancient DNA. Springer.

Maldonado C, Barnes CJ, Cornett C, Holmfred E, Hansen SH, Persson C, Antonelli A, Rønsted N. 2016. Phylogeny Predicts the Quantity of Antimalarial Alkaloids Within the Iconic Yellow Cinchona Bark (Rubiaceae: Cinchona calisaya). Frontiers in Plant Science 8:391.

Marra P \& Santella C. 2016. Cat Wars: the Devastating Consequences of a Cuddly Killer. 216 pages; Princeton University Press

PeerJ reviewing PDF | (2019:04:36735:1:2:NEW 16 Oct 2019) 
Matos-Maraví P, Duarte Ritter C, Barnes CJ, Nielsen M, Olsson U, Wahlberg N, Marquina D, Sääksjärvi I, Antonelli A. 2019. Biodiversity seen through the perspective of insects: 10 simple rules on methodological choices and experimental design for genomic studies. PeerJ Preprints 7:e26661v3; doi 10.7287/peerj.preprints.26661v3

McGuire JA, Cotoras DD, O'Connell B, Lawalata SZS, Wang-Claypool CY, Stubbs A, Huang X, Wogan GOU, Hykin SM, Reilly SB, Bi K, Riyanto A, Arida E, Smith LL, Milne H, Streicher JW, Iskandar DT. 2018. Squeezing water from a stone: high-throughput sequencing from a 145-year old holotype resolves (barely) a cryptic species problem in flying lizards. PeerJ 6, e4470, DOI:10.7717/peerj.4470.

Meineke EK, Davies TJ, Daru BH, Davis CC. 2019a. Biological collections for understanding biodiversity in the Anthropocene. Philosophical Transactions of the Royal Society B 374: 20170386, doi: 10.1098/rstb.2017.0386.

Meineke EK \& Davies TJ. 2019b. Museum specimens provide novel insights into changing plant-herbivore interactions. Philosophical Transactions of the Royal Society B 374: 20170393, doi: 10.1098/rstb.2017.0393.

Michener WK, Bildstein KL, McKee A, Parmenter RR, Hargrove WW, McClearn D, Stromberg M. 2009. Biological field stations: research legacies and sites for serendipity. BioScience 59, 300-310. http://dx.doi.org/10.1525/bio.2009.59.4.8

Mitchell BJ, Gillespie RG. 2007. Graduate Students Take to the Field in K-12 Education. PLoSBiology 5(6): e162. doi:10.1371/journal.pbio.0050162

Monardo B. 2019. Innovation districts as turbines of smart strategy policies in US and EU. Boston and barcelona experience. In Smart Innovation, Systems and Technologies, 100, pp. 322-335, doi: 10.1007/978-3-319-92099$3 \_38$

Morrison SA, Sillett TS, Funk WC, Ghalambor CK, Rick TC. 2017. Equipping the 22nd-Century Historical Ecologist. Trends in Ecology \& Evolution 32: 578-588.

National Research Council. 2014. Enhancing the Value and Sustainability of Field Stations and Marine Laboratories in the 21st Century The National Academies Press, Washington, DC. http://doi.org/10.17226/18806

Nirody JA, Jinn J, Libby T, Lee TJ, Jusufi A, Hu DL, Full RJ. 2018. Geckos Race Across the Water's Surface Using Multiple Mechanisms. Current Biology 28: 4046-4051, doi.org/10.1016/j.cub.2018.10.064 
Novotný V \& Y Basset. 2000. Rare species in communities of tropical insect herbivores: Pondering the mystery of singletons. Oikos 89: $564-572$.

Obst M, Vicario S, Lundin K, Berggren M, Karlsson A, Haines R, Williams A, Goble C, Mathew C, Güntsch A. 2017. Marine long-term biodiversity assessment suggests loss of rare species in the Skagerrak and Kattegat region. Marine Biodiversity, doi: 10.1007/s12526-071-0749-5

Page LM, MacFadden BJ, Fortes JA, Soltis PS, Riccardi G. 2015. Digitization of biodiversity collections reveal biggest data on biodiversity. Bioscience 65(9): 841-842.

Pauli JN, Newsome SD, Cook JA, Harrod C, Steffan SA, Baker C, Ben-David M, Bloom D, Brown G, Cerling T, Cicero C, Cook C, Dohm M, Eherlinger J, Federhen S, Frey B, Ghosh P, Graves G, Gropp R, Hobson K, Jordan C, O’Connell T, Pilaar Birch S, Poelen J, Ratnasingham S, Russell L, Stricker C, Uhen M, Yarnes C, Hayden B. 2017. Opinion: Why we need a centralized repository for isotopic data. Proceedings National Academy Sciences, USA 114: 2997-3001.

Phillips SJ, Dudik M. 2008. Modeling of species distributions with Max-Ent: new extensions and a comprehensive evaluation. Ecography 31:161-175

Phillips T. 2010. Sao Paulo fire destroys one of the largest collections of dead snakes. The Guardian 16 May 2010.

Phillips T. 2018. Brazil National Museum: as much as $90 \%$ of collection destroyed in fire. The Guardian 4 September 2018.

Portugal SJ, Cooper HJ, Zampronio CG, Wallace LL, Cassey P. 2010. Can museum egg specimens be used for proteomic analyses? Proteome Science 8:40.

Post RJ, Flook PK, Millest AL. 1993. Methods for the preservation of insects for DNA studies. Biochemical Systematics and Ecology 21:85-92, https://doi.org/10.1016/0305-1978(93)90012-g

von Proschwitz T. 1997. Arion lusitanicus MABILLE and A. rufus (L.) in Sweden: A comparison of occurrence, spread and naturalization of two alien slug species. Heldia 4 Sonderheft 5: 137-138.

Raffauf RF, von Reis Altschul S. 1968. The Detection of Alkaloids in Herbarium Material. Economic Botany 22:267-269.

Ramos-Madrigal J, Smith BD, Moreno-Mayar JV, Gopalakrishnan S, Ross-Ibarra J, Gilbert MTP, Wales N. 2016. Genome Sequence of a 5,310-Year-Old Maize Cob Provides Insights into the Early Stages of Maize Domestication. Current Biology 26: 3195-3201, https://doi.org/10.1016/j.cub.2016.09.036 
Ratnasingham \& Hebert. 2007. BOLD: The Barcode of Life Data System (www.barcodinglife.org). Molecular Ecology Notes 7:355 -364, doi: 10.1111/j.1471-8286.2006.01678.

Ricklefs RE. 2006. Global variation in the diversification rate of passerine birds. Ecology 87(10):2468-78.

Riesa L, Zipkin EF, and RP Guralnick. 2019. Tracking trends in monarch abundance over the20th century is currently impossible using museum records. Proceedings of the National Academy of Sciences of the United States of America 116:13745-13748, https://www.pnas.org/cgi/doi/10.1073/pnas.1904807116

Roggenbuck-Wedemayer M, Bærholm Schnell I, Blom N, Bælum J, Bertelsen MF, Sicheritz-Pontén T, Johannes Sørensen S, Gilbert MTP, Graves GR, Hansen LH. 2014. The microbiome of New World vultures, Nature Communications 5:5498, doi:10.1038/ncomms6498.

Rocha LA, Aleixo A, Allen G, Almeda F, Baldwin CC, Barclay MVL, Bates JM, Bauer AM, Benzoni F, Berns CM, Berumen ML, Blackburn DC, Blum S, Bolaños F, Bowie RCK, Britz R, Brown RM, Cadena CD, Carpenter K, Ceríaco LM, Chakrabarty P, Chaves G, Choat JH, Clements KD, Collette BB, Collins A, Coyne J, Cracraft J, Daniel T, de Carvalho MR, de Queiroz K, Di Dario F, Drewes R, Dumbacher JP, Engilis Jr. A, Erdmann MV, Eschmeyer W, Feldman CR, Fisher BL, Fjeldså J, Fritsch PW, Fuchs J, Getahun A, Gill A, Gomon M, Gosliner T, Graves GR, Griswold CE, Guralnick R, Hartel K, Helgen KM, Ho H, Iskandar DT, Iwamoto T, Jaafar Z, James HF, Johnson D, Kavanaugh D, Knowlton N, Lacey E, Larson HK, Last P, Leis JM, Lessios H, Liebherr J, Lowman M, Mahler DL, Mamonekene V, Matsuura K, Mayer GC, Mays Jr. H, McCosker J, McDiarmid RW, McGuire J, Miller MJ, Mooi R, Mooi RD, Moritz C, Myers P, Nachman MW, Nussbaum RA, Foighil DÓ, Parenti LR, Parham JF, Paul E, Paulay G, Pérez-Emán J, Pérez-Matus A, Poe S, Pogonoski J, Rabosky DL, Randall JE, Reimer JD, Robertson DR, Rödel M-O, Rodrigues MT, Roopnarine P, Rüber L, Ryan MJ, Sheldon F, Shinohara G, Short A, Simison WB, Smith-Vaniz WF, Springer VG, Stiassny M, Tello JG, Thompson CW, Trnski T, Tucker P, Valqui T, Vecchione M, Verheyen E, Wainwright PC, Wheeler TA, White WT, Will K, Williams JT, Williams G, Wilson EO, Winker K, Winterbottom R, Witt CC. 2014. Specimen collection: an essential tool. Science 344 (6186), 814.

Rouhan G, Chagnoux S, Dennetière B, Schäfer V, Pignal M. 2016. "The herbonauts website: Recruiting the general public to acquire the data from herbarium labels." Botanists of the Twenty-First Century: Roles, Challenges and Opportunities. United Nations Educational, Scientific and Cultural Organisation: 143-148. 


\section{Rowe KC, Singhal S, Macmanes MD, Ayroles JF, Morelli TL, Rubidge EM, Bi KE, Moritz CC. 2011.} Museum genomics: low-cost and high-accuracy genetic data from historical specimens. Molecular Ecology Resources 11(6):1082-1092.

Ruane S, Austin CC. 2017. Phylogenomics using formalin-fixed and 100+ year-old intractable natural history specimens. Molecular Ecology Resources 17:1003-1008, doi:10.1111/1755-0998.12655.

Schindel DE, Cook JA. 2018. The next generation of natural history collections. PLoS Biol 16(7): e2006125, https://doi.org/10.1371/journal.pbio.2006125

Schmitt CJ, Cook JA, Zamudio KR, Edwards SV. 2018. Museum specimens of terrestrial vertebrates are sensitive indicators of environmental change in the Anthropocene. Phil. Trans. R. Soc. Lond. B. Biol. Sci 374: 20170387

Sebastian P, Schaefer H, Telford IRH, Renner SS. 2010. Cucumber (Cucumis sativus) and melon $(C$. melo) have numerous wild relatives in Asia and Australia, and the sister species of melon is from Australia. Proceedings of the National Academy of Sciences of the United States of America 107:14269-14273.

Shultz AJ, Baker AJ, Hill GE, Nolan PM, Edwards SV. 2016. SNPs across time and space: population genomic signatures of founder events and epizootics in the House Finch (Haemorhous mexicanus). Ecology and Evolution 6, 7475-7489.

Silvertown J, Harvey M, Greenwood R, Dodd M, Rosewell J, Rebelo T, Ansine J, McConway K. 2015. Crowdsourcing the identification of organisms: A case-study of iSpot. ZooKeys 480:125-146, doi: 10.3897/zookeys.480.8803

Silvestro D, Salamin N, Schnitzler J. 2014. PyRate: a new program to estimate speciation and extinction rates from incomplete fossil data. Meth. Ecol. Evol. 5:1126-1131, doi: 10.1111/2041-210X.12263

Slingsby JA, Merow C, Aiello-Lammens M, Allsopp N, Hall S, Kilroy Mollmann H, Turner R, Wilson AM and JA Silander Jr. 2017. Intensifying postfire weather and biological invasion drive species loss in a Mediterranean-type biodiversity hotspot. Proceedings of the National Academy of Sciences of the United States of America 114(18):4697-4702.

Slon V, Mafessoni F, Vernot B, de Filippo C, Grote S, Viola B, Hajdinjak M, Peyrégne S, Nagel S, Brown S, Douka K, Higham T, Kozlikin MB, Shunkov MV, Derevianko AP, Kelso J, Meyer M, Prüfer K, Pääbo S. 
2018. The genome of the offspring of a Neanderthal mother and a Denisovan father. Nature 561:113 — 117, $\underline{\text { https://doi.org/10.1038/s41586-018-0455-x }}$

Smith BE, Johnston MK, Lücking R. 2016. From GenBank to GBIF: Phylogeny-Based Predictive Niche Modeling Tests Accuracy of Taxonomic Identifications in Large Occurrence Data Repositories. PLoS ONE 11(3):e0151232, https://doi.org/10.1371/journal.pone.0151232

Smith CI, Chamberlain AT, Riley MS, Stringer C, Collins M. 2003. The thermal history of human fossils and the likelihood of successful DNA amplification. Journal of Human Evolution 45, 203-217.

Smith, O. et al. 2014. Genomic methylation patterns in archaeological barley show de-methylation as a timedependent diagenetic process. Sci. Rep. 4:5559.

Smith, R.W. et al. 2015. Detection of cytosine methylation in ancient DNA from five Native American populations using bisulfite sequencing. PLoS ONE 10, e0125344 35.

Staats M, Cuence A, Richardson JE, Vrielink-van Ginkel R, Petersen G, Seberg O, Bakker FT. 2011. DNA damage in plant herbarium tissue. PLOS ONE 6: $e 28448$

Staats M, Erkens RHJ, van de Vossenberg B, Wieringa JJ, Kraaijeveld K, Stielow B, Geml J, Richardson JE, Bakker FT. 2013. Genomic Treasure Troves: Complete Genome Sequencing of Herbarium and Insect Museum Specimens. PLoS ONE 8(7): e69189, doi:10.1371/journal.pone.0069189.

ter Steege H, Haripersaud PP, Bánki OS, and Feike Schieving. 2011. A model of botanical collwectors' behaviour in the field: never the same species twice. American Journal of Botany 98(1): 31-37.

Suarez AV, Tsutsui ND. 2004. The Value of Museum Collections for Research and Society. Bioscience 54:66-74

Troudet J, Vignes-Lebbe R, Grandcolas Ph, Legendre F. 2018. The Increasing Disconnection of Primary Biodiversity Data from Specimens: How Does It Happen and How to Handle It?, Systematic Biology 67: 11101119, https://doi.org/10.1093/sysbio/syy044

Vane-Wright RI \& Cranston PS. 1992. Collections and systematics. Australian Biologist 5: 14-18.

Veijalainen A, Wahlberg N, Broad GR, Erwin TL, Longino JT, Sääksjärvi, IE. 2012. Unprecedented ichneumonid parasitoid wasp diversity in tropical forests. Proc. R. Soc. B 279:4694-4698, doi:10.1098/rspb.2012.1664.

Webster MS. 2017. The Extended Specimen: Emerging Frontiers in Collections-Based Ornithological Research. Boca Raton, FL, USA: CRC Press. 
Welker F, Soressi M, Rendu W, Hublin J-J, Collins M. 2015. Using ZooMS to identify fragmentary bone from the Late Middle/Early Upper Palaeolithic sequence of Les Cottés, France. Journal of Archaeological Science 54:279-286.

Wen J, Egan AN, Dikow RB, Zimmer EA. 2015. Utility of transcriptome sequencing for phylogenetic inference and character evolution. in: Hörandl, E. \& Appelhans, M.S. (eds.), Next-Generation Sequencing in Plant Systematics. Chapter 2, http://dx.doi.org/10.14630/000003@ International Association for Plant Taxonomy (IAPT)

Wepprich T. 2019. Monarch butterfly trends are sensitive to unexamined changes in museum collections over time. Proceedings of the National Academy of Sciences of the United States of America 116: 13742 -13744, https://www.pnas.org/cgi/doi/10.1073/pnas.1903511116

Wilson EO. 2003. The encyclopedia of life. Trends in Ecology and Evolution 18: 77-80.

Woinarski J, Legge S, Dickman C. 2019. Cats in Australia: Companion and Killer. 344 pages, CSIRO Publishing Yanagihara R, Gu SH, Song J-W. 2015. Expanded host diversity and global distribution of hantaviruses: Implications for identifying and investigating previously unrecognized hantaviral diseases. In: Shapshak P, Sinnott JT, Somboonwit C, Kuhn J, eds. Global Virology. Identifying and Investigating Viral Diseases. New York: Springer-Verlag. 161 \pm 198 .

Yates TL. Mills JN, Parmenter CA, Ksiazek TG, Parmenter RR, van de Castle JR, Calisher CH, Nichol ST, Abbott KD, Young JC, Morrison ML, Beaty BJ, Dunnum JL, Baker RJ, Salazar-Bravo J, Peters CJ. 2002. The ecology and evolutionary history of an emergent disease: Hantavirus pulmonary syndrome. Bioscience, 52: 989-998.

Yesson C, Brewer PW, Sutton T, Caithness N, Pahwa JS, Burgess M, Gray WA, White RJ, Jones AC, Bisby FA, Culham A. 2007. How Global Is the Global Biodiversity Information Facility? PLoSONE 2(11): e1124, doi:10.1371/journal.pone.0001124

Yoshida K, Burbano HA, Krause J, Thines M, Weigel D, Kamoun S. 2014. Mining Herbaria for Plant Pathogen Genomes: Back to the Future. PLoS Pathog 10(4): e1004028, doi:10.1371/journal.ppat.1004028

Yoshida K, Sasaki E, Kamoun S. 2015. Computational analyses of ancient pathogen DNA from herbarium samples: Challenges and prospects. Frontiers in Plant Science 6, Article number 771, 6p 
1081 Zeyl E, Marcotegui P, Harris PD, Bakke TA, Bachmann L. 2012. Nye parasitter fra gamle fisk / New parasites 1082 from old fish. Naturen 136, 274-280.

1083 Zhang Q, Hill GE, Edwards SV, Backström N. 2014. A house finch (Haemorhous mexicanus) spleen

1084 transcriptome reveals intra- and interspecific patterns of gene expression, alternative splicing and genetic

1085 diversity in passerines. BMC Genomics 15:305. 


\section{Table 1 (on next page)}

Main global and local aggregators of biodiversity data. 
Table 1. Main global and local aggregators of biodiversity data.

Volume of

Acronym Mission

Funding; scope $\quad$ Type of data

records (M)

\begin{tabular}{|c|c|c|c|c|}
\hline ADBC & Advancing Digitization of Biodiversity Collections & US & & \\
\hline ALA & Atlas of Living Australia. https://www.ala.org.au/ & Australia & $\begin{array}{l}\text { Observations, } \\
\text { specimens }\end{array}$ & 84.8 \\
\hline BOLD & Barcode of Life Database & Canada; global & & 6.8 \\
\hline eBird & $\begin{array}{l}\text { Citizen science: the world largest biodiversity-related citizen } \\
\text { science project, gathering information on bird sightings, archive it, } \\
\text { and "freely share it to power new data-driven approaches to science, } \\
\text { conservation and education." https://ebird.org/home }\end{array}$ & Global & Observations & 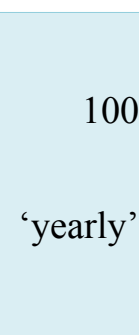 \\
\hline EOL & $\begin{array}{l}\text { Encyclopedia of Life; Global access to knowledge about life on } \\
\text { Earth }\end{array}$ & $\begin{array}{l}\text { Australia, Egypt, } \\
\text { US; global }\end{array}$ & $\begin{array}{l}\text { Species } \\
\text { descriptions }\end{array}$ & $<1,9$ \\
\hline
\end{tabular}




\begin{tabular}{|c|c|c|c|c|}
\hline GBIF & Global Biodiversity Information Facility & Global & $\begin{array}{l}\text { Observations, } \\
\text { specimens }\end{array}$ & 1300 \\
\hline GGBN & Global Genome Biodiversity Network & Global & $\begin{array}{l}\text { DNA, tissues, } \\
\text { environmental } \\
\text { samples }\end{array}$ & 3.8 \\
\hline GloBI & $\begin{array}{l}\text { Global Biotic Interactions; species interaction data by combining } \\
\text { existing open datasets. https://www.globalbioticinteractions.org/ }\end{array}$ & US; global & $\begin{array}{l}\text { Species } \\
\text { interaction data } \\
\text { e.g., predator- } \\
\text { prey, pollinator- } \\
\text { plant, pathogen- } \\
\text { host, parasite-host }\end{array}$ & $>0.7$ \\
\hline HOLOS & $\begin{array}{l}\text { Berkeley Ecoinformatics Engine: accessing and visualizing } \\
\text { integrated biological and environmental datasets to address } \\
\text { questions of global change biology. https://holos.berkeley.edu/ }\end{array}$ & US; global & $\begin{array}{l}\text { Different kinds of } \\
\text { biological and } \\
\text { environmental } \\
\text { datasets }\end{array}$ & n.a. \\
\hline iBOL & $\begin{array}{l}\text { International Barcode of Life; extending BOLD's coverage. } \\
\text { iBOL's forthcoming BIOSCAN will activate a biomonitoring }\end{array}$ & Canada; global & DNA barcodes & see BOLD \\
\hline
\end{tabular}




\begin{tabular}{|c|c|c|c|c|}
\hline & $\begin{array}{l}\text { system for half the world's ecoregions, metabarcoding assemblages } \\
\text { and studying species interactions from } 2,500 \text { sites. iBOL.org }\end{array}$ & & and metadata & \\
\hline IDEA & $\begin{array}{l}\text { Island Digital Ecosystem Avatar; place-based systems ecology for } \\
\text { building simulations of social-ecological systems }\end{array}$ & US; Moorea & $\begin{array}{l}\text { Specimens, } \\
\text { observations }\end{array}$ & $?$ \\
\hline iDigBio & $\begin{array}{l}\text { Integrated Digitized Biocollections; digitisation and databasing of } \\
\text { US specimen collections }\end{array}$ & US & Specimens & 117.5 \\
\hline iNaturalist & $\begin{array}{l}\text { Citizen science: one of the world's most popular nature apps, } \\
\text { sharing observations globally; https://www.inaturalist.org/ }\end{array}$ & US; global & Observations & $<1$ \\
\hline LifeWatch & $\begin{array}{l}\text { Biodiversity research, -management and -conservation priority } \\
\text { setting }\end{array}$ & Europe & Research tools & n.a. \\
\hline iSpot & $\begin{array}{l}\text { Citizen science: experts helping citizen community to identify its } \\
\text { wildlife observations. https://www.ispotnature.org/ }\end{array}$ & UK; global & $\begin{array}{l}\text { Species } \\
\text { identifications }\end{array}$ & 0.030 \\
\hline MoL & $\begin{array}{l}\text { Map of Life; providing species range and dynamics information } \\
\text { and species lists for any geographic area. https://mol.org/ }\end{array}$ & Global & $\begin{array}{l}\text { Occurrences, } \\
\text { observations }\end{array}$ & 8.8 \\
\hline NCBI & National Center for Biotechnology Information & Global & $\begin{array}{l}\text { Nucleotide and } \\
\text { amino acid }\end{array}$ & 0.37 \\
\hline
\end{tabular}




\begin{tabular}{|c|c|c|c|c|}
\hline & & & $\begin{array}{l}\text { sequences; } \\
\text { genome } \\
\text { annotations }\end{array}$ & species covered \\
\hline NEON & $\begin{array}{l}\text { National Ecological Observatory Network; continental-scale } \\
\text { environmental data, infrastructure for research, educational tools to } \\
\text { work with large data. https://www.neonscience.org/ }\end{array}$ & US & Observations & ? \\
\hline OToL & $\begin{array}{l}\text { Open Tree of Life; construct a comprehensive, dynamic and } \\
\text { digitally-available tree of life by synthesizing published } \\
\text { phylogenetic trees along with taxonomic data. } \\
\text { https://tree.opentreeoflife.org/ }\end{array}$ & US; global & $\begin{array}{l}\text { Phylogenetic trees } \\
\text { and taxonomies }\end{array}$ & $\begin{array}{r}2.6 \\
\text { OTU's in } \\
\text { taxonomy }\end{array}$ \\
\hline Traitbase & $\begin{array}{l}\text { Ecological species characteristics, individual level species } \\
\text { information. https://traitbase.info/whatis }\end{array}$ & Spain; global & $\begin{array}{l}\text { Specific } \\
\text { characteristics } \\
\text { e.g. body size, } \\
\text { diet or fecundity }\end{array}$ & ? \\
\hline
\end{tabular}


Table 2 (on next page)

Specimens and best curation practices for the future. 
1 Box 1. Citizen Science examples.

2 Citizen science can contribute significantly to building collections, as for instance seen in many

3 entomological collections that grow these days by amateur entomologists donating their well

4 curated collections for science. eBird and iNaturalist are excellent examples of connecting

5 citizen with science in a highly-efficient manner (and then feeding into GBIF). The Gothenburg

6 Natural History Museum (GNM) malacological collections have benefitted tremendously by

7 citizen science efforts with devoted ('advanced') amateurs donating their often well-curated

8 private collections. Based on these collections, which can be considered 'environmental

9 archives', Bolotov et al. (2018) could infer from freshwater pearl mussel collections that

10 morphology has changed in time correlated to environmental alteration and climate change.

11 Based on historical and recent specimens from extensive geographical sampling, the authors

12 concluded that climate change may well have accelerated the population decline in pearl mussels

13 over the last 100 years. The study underlines the importance of preserving large collections

14 (many individuals) to enable meaningful statistical analysis of morphological measurements.

15 Below is another example from the GNM concerning garden slu gs sent in by the general public.

16 Since 1986 the Gothenburg Natural History Museum (GNM) has offered a slug-identification

17 service to the public. The project was initiated as the invasive Spanish slug (Arion vulgaris

18 Moquin-Tandon) began to spread rapidly over the country, prompting the need to establish a way

19 to follow the spread and the colonisation process. As the slug spreads passively, mainly by the

20 trade with ornamental plants and also with garden soil, it easily establishes in residential areas,

21 where it mass-propagates and causes severe damage to vegetables and plants. A proper

22 determination of these species requires dissection, a service offered by GNM. The project was

23 advertised on TV, radio, in the newspapers and on museum web pages and GNM even offered to 
24 send out a transportation box which could easily be returned by mail. The response from the

25 public was immense, and up to today GNM has received $>6000$ samples with slugs from all over the country. Together with the box, GNM sent out a questionnaire asking information about

27 first year of occurrence, possible way of introduction etc. After determination of the specimens the senders got information of species identity, and in case $A$. vulgaris was concerned also advice for control measurements. Hence the project has been beneficial for both the gardeners and the museum. The colonisation process could be followed in detail and much information on the biology and behaviour of the species, as well as on the garden fauna of snails and slugs, was obtained. The latter included several other invasive species, from different parts of the country, and the development of this fauna over more than four decades could be monitored both geographically and chronologically. Furthermore, as at least one specimen from each species in the samples was preserved inEtOH, extensive material is available for DNA analysis, which has proved highly useful as the taxonomy of the Spanish slugs is complicated, involving hybridisation with other native and introduced species (von Proschwitz, 1997). 
Table 3 (on next page)

Specimens and Pathogens. 


\section{Box 2. Specimens and Pathogens}

2 Museum collections have provided fundamental infrastructure for identifying and mitigating

3 emerging pathogens and zoonotic diseases by public health agencies (Dunnum et al., 2017) such

4 as the Centers for Disease Control (CDC). When a new pathogen emerged in 1993 in the

5 southwestern United States, rapidly killing 7 people, authorities needed to know: had this

6 pathogen accidently been released into the wild, or was it a newly evolved pathogen, or had the

7 virus always been present and simply not previously identified? Without the availability of

8 specimen archives, scientists would not have been able to efficiently determine the pathogen

9 source and answer these fundamental questions. Large tissue archives from the Museum of

10 Southwestern Biology and other museums (Yates et al., 2002) enabled virologists to quickly

11 identify that this previously unknown zoonotic hantavirus pathogen was hosted by the locally

12 common deer mouse (Peromyscus maniculatus). This virus is apparently transmitted to humans

13 through inhalation of viral infected feces. Subsequent emergence of other human cases elsewhere

14 in the Americas (e.g., Chile, Argentina, Panama), but with higher mortality, mobilized other

15 specimen-based research efforts that identified other new strains of hantaviruses in many rodent species over the next 2 decades and on multiple continents. More recently, museum specimens of other groups of mammals were screened, leading to a radically reshaped understanding of hantavirus evolution, ecology and host occurrence (Yanagihara et al., 2015). Not only were more rodent host species for these viruses identified, but numerous species of shrews, moles, and bat species worldwide also harbor their own hantaviruses. These specimens originated from multiple continents and the new discoveries significantly expand the potential risk to humanity of these pathogens and increase the burden on public health systems worldwide. 
23 Other examples of pathogen outbreaks have examined historical progression of diseases often decades or centuries after the outbreak (Schmitt et al., 2018). The impact of an invasive bacterial pathogen from poultry on native songbirds has been studied using avian tissue samples collected just prior to the outbreak in the eastern US, albeit without any foreknowledge of the impending epizootic (Hess et al., 2007; Shultz et al., 2016). The Norwegian fish fauna is well documented in the scientific collection of the Natural History Museum, University of Oslo and collection material was screened for monogenean ectoparasitic flatworms of the genus Gyrodactylus that were (unintendedly) collected along with the fish (Zeyl et al. 2012). This yielded 13 flatworm species that are new to science, and an additional seven parasite species new to Norway. Three Gyrodactylus species were also recorded from new fish hosts, and in particular G. pterygialis appeared to have a broad range of host species, helping fishery biologists tremendously in understanding and managing fish populations. From plants, Yoshida et al. $(2014 ; 2015)$ used potato herbarium in order to determine the genotype of the Phytophtera infestans strain that caused the great Irish potato famine in the 19th century (and concluded it was a 'one-off' type, never seen again). Herbarium DNA was also crucial in discovering ancient alleles in the grass Alopecurus myosuroides that are relevant to herbicide resistance but pre-dating human influence (Délye et al., 2013). Studies using genomic data of a 5,310-year-old maize cob (Ramos-Madrigal et al., 2016) have shown that our understanding of the process of domestication and early selection pressures needs adjusting. 
Table 4 (on next page)

Citizen Science.

Examples of Citizen Science projects from the malacology group of the Gothenburg Natural History Museum. 
1 Box 3. Specimens and best curation practices for the future

2 Collecting. Recommendations for best preservation techniques for new specimens during field

3 collection are as important as the final storage conditions for improving specimen long-term

4 utility for genomics (Matos-Maraví et al., 2019). Documenting treatment practices is also key to

5 facilitating future analyses enabled by as yet undiscovered technologies. The plethora of

6 technological uses of museum specimens calls for a re-evaluation of how specimens are

7 preserved. For centuries, plants have been pressed, animals mounted, marine specimens ethanol-

8 or formalin-fixed and fungi dried. Although these standard preservation methods should still

9 continue, if only because they constitute the bulk of biological collections thus far and have a

10 proven track record of fostering discovery, whenever possible researchers should try to sample

11 additional types of specimen parts, and organs and meta-data.

12 Storing. More studies need to be undertaken to improve relevant protocols for the long-term storage of specimens and tissues. Like digitization, banking of genetic resources by museums is an area of rapid innovation, particularly as next-generation sequencing methods have become more common. As museum tissue collections are accessed more frequently for genome projects, it has also become clear that the preservation standards and types of tissues preserved in museums are often inadequate for supporting the genomics enterprise. For example, a typical museum tissue sample from a bird, even if frozen in nitrogen hours after sacrifice in the field, yields DNA qualities and lengths unsuitable for $3^{\text {rd }}$ generation long-read sequencing platforms such as PacBio and Oxford Nanopore. Such technologies rely on the use of long DNA fragments to start with, requiring specimen tissues be frozen immediately (within $>10-15$ minutes) upon collection. Although it may be difficult to use liquid nitrogen in the field, one solution is to use so called Dry Shippers, which are dewars designed for safe transportation of tissues at the same 
temperature as liquid nitrogen but without actually containing any free liquid nitrogen. Such shippers are routinely allowed for transportation back to the lab by airlines and can often hold cold temperatures for $\sim 3$ weeks. Innovations in cryogenics are likely to transform collecting of genomic resources by museums in the future. But even here, some of us have noted poor DNA retrieval from tissues collected with standard field-protocols and ultimately preserved cryogenically (S. Edwards, pers. obs.). For birds, best practices for genome sequencing may not include freezing in the short term, which can fragment DNA, but rather unfrozen archiving of blood, which will preserve the longest DNA fragments. What seems to be most important is that DNA (and RNA) degradation is stopped as fast as possible after collection. For example, for birds, one way to achieve long DNA fragments for next-generation sequencing is to use unfrozen blood stored in Queen's lysis buffer, which has been used by ornithologists for decades and takes advantage of birds' nucleated red blood cells. Blood stored in this way, with minimal shaking that will cause shearing, is a reliable source of high molecular weight DNA and has been shown to yield better genome assemblies than DNA retrieved from museum-grade frozen tissues (S. Edwards, G. Bravo, pers. obs). An alternative could be to store collections in the field in DMSO, although this appears to prevent RNA sequencing (Irestedt, unp. data). On the other hand, whether or not EDTA or $95 \% \mathrm{EtOH}$ was used for DNA sample storage can be important too for successful long read sequencing (MI, pers. obs.). Still, we can take comfort that even from dried, centuries-old traditional specimens, valuable genetic information can readily be obtained by hybrid-capture and other approaches (Bi et al., 2013; Staats et al., 2013). Such best-practices for fieldwork and storage of genetic resources needs to be shared more widely and rapidly among the museum community. A useful platform for identifying both repositories and tissues for a 
46 wide range of taxa, often called biobanks, is provided by the Global Genomic Biodiversity

47 Network mentioned above (GGBN see http://www.ggbn.org/ggbn_portal/)).

48 Below we outline various updates in storage of genetic resources for both animals and plants,

49 highlighting issues facing museum curators and collection managers looking at the future.

Genomics is a key source of information and rapidly changing area in which the scope and potential of future applications are particularly promising. Nonetheless, there are several factors known to limit the utility of specimens for genomic analyses. For example, using 'methylated spirit' (methanol containing alcohol) instead of pure alcohol for field preservation of animal tissue can severely hamper retrieval of usable DNA later on (Post \& al., 1998) (see Box 1). Heat treatment of plants, as typically applied in most historic herbarium collections, was found to lower genomic copy numbers but not cause significant miscoding lesions (Bakker, 2015; Staats et al., 2011). Conventional x-rays (as opposed to x-ray computed tomography with digital imaging) of mummies and bone or using pesticides on insect collections all negatively affect or destroy DNA (Gotherstrom et al., 1995). Use of formalin to preserve specimens limits extraction of usable DNA from both animal or plant tissues as it causes cross-links among DNA molecules, preventing PCR (Ruane and Austin, 2017; McGuire et al., 2018).

For historic samples, significant progress in securing biopolymers has been made and museum and ancient genomics has attracted considerable interest, from researchers and industry (Hofreiter \& al., 2015; Lindqvist \& Rajora, 2019). Still, although some DNA sequencing technologies work well with degraded DNA, such as in herbarium DNA using Illumina sequencing (Staats \& al., 2013; Bakker et al., 2016; Hart et al., 2016), single-molecule, '3 3 rd generation', genome sequencing will never be applicable for most museum-preserved specimens given the fragmented nature of their DNA. 
'Re-sequencing', i.e. sequencing and mapping reads against a related reference genome sequence, has been successful in museum plants, fungi and insects (Bi et al., 2014; Staats et al., 2013). For organisms with relatively small genome sizes, such as birds the price for resequencing a genome from a study skin has become so low that curators of bird collections may consider to actually requiring complete genome sequencing for tissue from old museum samples. In this case, all parties ideally would benefit, the user for having access to the specimen, the museum for putting a halt to further specimen deterioration (as the genome sequence has been generated), and the next user for have both specimen and genome sequence available. That said, it is difficult to predict how DNA extraction techniques may evolve, and perhaps require considerably lower tissue amounts to produce higher DNA yields, meaning that high-throughput DNA extraction without an immediate use (DNA banking) is not an obvious choice for museums.

Often scientists endeavour to see inside museum specimens. Previous approaches such as dissection or histology are invasive techniques that necessarily result in the destruction of other data. Although recent imaging techniques (diceCT; Gignac et al., 2016) enable largely nondestructive work on these questions in non-model organisms preserved in alcohol, they do not completely ameliorate data loss due to selectivity in field materials preserved. Specimen field preparations may include freezing fresh tissue for DNA, preserving skeletons and skins but removing most internal organs and muscles. The latter obviously limits the kinds and diversity of research that can ultimately be performed on such specimens. For example, the vocal organ of birds was often not collected in birds despite the perceived importance of bird song and other vocalization. Some now broadly used imaging techniques (e.g. diceCT) have not been studied 
91 for their effects on DNA/RNA amplification from formalin or alcohol-preserved specimens, and

92 it is unknown if they further inhibit downstream molecular work involving these specimens.

93 For most large multicellular organisms, it is challenging to collect large numbers of tissues.

However, more portions of an organism can be feasibly preserved before discarding tissues when making new collections, particularly of common, easily accessed species. For example, at the Museum of Comparative Zoology at Harvard University, a typical avian specimen is now accompanied by 7-10 cryovials filled with DNA- and RNA-ready tissues from different organs, as well as at least one tube of unfrozen but refrigerated blood for genome sequencing. Such sampling will no doubt pose space challenges for long-term storage (which could be partially solved through the use of space-efficient biobanks), but is essential for, for instance, a deep understanding of the effects of anthropogenic change on biodiversity (Schmitt et al., 2018). Integrating new imaging techniques into museum work flows will increase documentation prior to destruction (e.g. for genomic work). For instance, the Thermal Age Web Tool (http://thermal$\underline{\text { age.eu/) }}$ was developed to help collections managers and users to quantify the risks associated with destructive analysis of specimens, based on calculated 'thermal ages' (Smith et al., 2003). The Synthesis of Systematic Resources programme (see http://www.synthesys.info/jointresearch-activities/) provides further recommendations for non-destructive sampling of museum specimens and decision analysis as to how to best sample specimens for genomic research. Lower price points for acquisition of genome data and some imagining techniques makes defining these best practices more urgent.

Transcriptomics and Epigenomics. The ever-increasing number of genome sequences becoming available can be efficiently explored in terms of gene function through transcriptomics - the sequencing of all transcribed mRNA expressed at a certain time, physiological or developmental 
114 state for a particular tissue. In this way, the 1Kite (http://www.1kite.org/) and 1kp

115 (https://sites.google.com/a/ualberta.ca/onekp/) projects, assembling 1000 transcriptomes of

116 insects and plants, respectively, have expedited progress in both comparative and functional

117 genomics and a better understanding of gene function across these clades (see for instance

118 Gitzendanner \& al., 2018). We would expect future specimens to play an increasing role in this

119 respect, but only if we make sure to store our specimens in such a way that RNA is preserved,

120 for instance by rapid cryogenic storage of use of RNA-friendly buffers like RNA-later.

121 Additionally, a diversity of epigenomics approaches, such as methylation, Chip-seq and ATAC-

122 seq, are emerging and potentially of great use to the field of evolutionary biology (Grayson et

$123 a l ., 2017)$. Epigenomics is already commonly applied in evolutionary studies of adaptation and

124 development, and has recently made headway in examining epigenetic maps of extinct human

125 and plant populations (Llamas et al., 2012; Gokhman et al., 2014; Smith et al., 2014; 2015). Best

126 practices for preservation of biomaterials for epigenetics has not yet been discussed in the

127 literature, and will be an important additional consideration for museum curators in the future.

128 Proteomics. Given future technological developments, it is likely that proteomes will be determined and used for further functional studies across the Tree of Life. Additionally, collagen from bone tissues have been demonstrated to give species-level amino acid variation from specimens several millions of years old using a ZooMS approach (Welker et al., 2015). Portugal et al. (2010) report on proteomics in museum egg specimens and conclude that current approaches to proteomics in such specimens may be limited in coverage of the proteome. In any case, storing tissues in the best possible ways for proteomics, ideally, cryogenically in order to stop proteases from working, now ensures that such analyses can be conducted in the near future. 
136 Secondary metabolites. Compounds such as alkaloids, glucosinolates, furanocoumarins,

137 flavonoids or terpenes can be measured in museums tissues, especially from plants (Berenbaum

138 \& Zan 1998; Colegate \& al., 2014; Mithen et al., 2010; Raffauf \& Von Reis Altschul, 1968).

139 Access to such metabolites enables testing historic biological hypotheses such as past responses

140 to change in herbivores and climate; but also in case of invasive species and testing what

141 secondary compounds may have driven invasive success in species such as Vincetoxicum nigrum

142 (Asclepiadaceae) (Liede-Schuman \& al., 2016).

143 Stable isotopes. Advancement of techniques for studying specimens include measuring of stable

144 isotopes, allowing monitoring environmental/atmospheric changes over time, given a time series

145 of museum specimens (reviewed in Schmitt et al., 2018). Because elements are not expected to

146 degrade over time like biopolymers do, proper specimen storage conditions for isotope analysis

147 is probably not critical. Limiting factors in such studies now is the availability of robust spatial

148 sampling and time series of specimens for analysis. Properly tracking the vast quantities of data

149 that are generated in these analyses directly to the specimens is also a challenge (Pauli et al.,

150 2017).

151

152

153

154

155

156

157

158

Non-standard tissues. Classical botanical specimens comprise branches with leaves and fertile organs (flowers, fruits). For some vertebrates, such as birds and mammals, it is primarily the external morphology that is preserved in collections, whereas for amphibians, reptiles and fish, preservation in formalin and/or alcohol can yield DNA sequences with some effort (Ruane et al., 2017; McGuire et al., 2018). Many biobanks, particularly in US museums, now also include samples of frozen blood and tissue from vertebrates, typically heart, liver and muscle. However, many other parts of organisms not conventionally stored in museums are becoming important in the effort to monitor global change. For instance, there is great interest among diverse scientists 
159 in investigating the microbiome of species - including the bacteria present in the digestive 160 system, and what roles they may have to the species' adaptations to the local environments 161 (Roggenbuck et al., 2014; Alvisatos et al., 2015; Ingala et al., 2018). Similarly, tree bark may

162 provide important information on chemical defenses of plants and hold implications for medical 163 applications (Maldonado et al., 2016). Transcriptome studies in vertebrates are becoming 164 increasingly common as a means to study species' ability to adapt to changing environments and 165 anthropogenic change (e.g., Zhang et al., 2014) and are widely used in phylogenomics of 166 invertebrates and plants (Wen et al., 2015). Such studies encourage careful sampling and 167 preservation of whole organisms or all organs separately when appropriate. 
Figure 1

The centrality of natural history collections to evolutionary biology and public understanding.

Users, contributors and stakeholders of natural history collections are indicated; yellow arrows represent data flow, green arrows the flow of specimens.

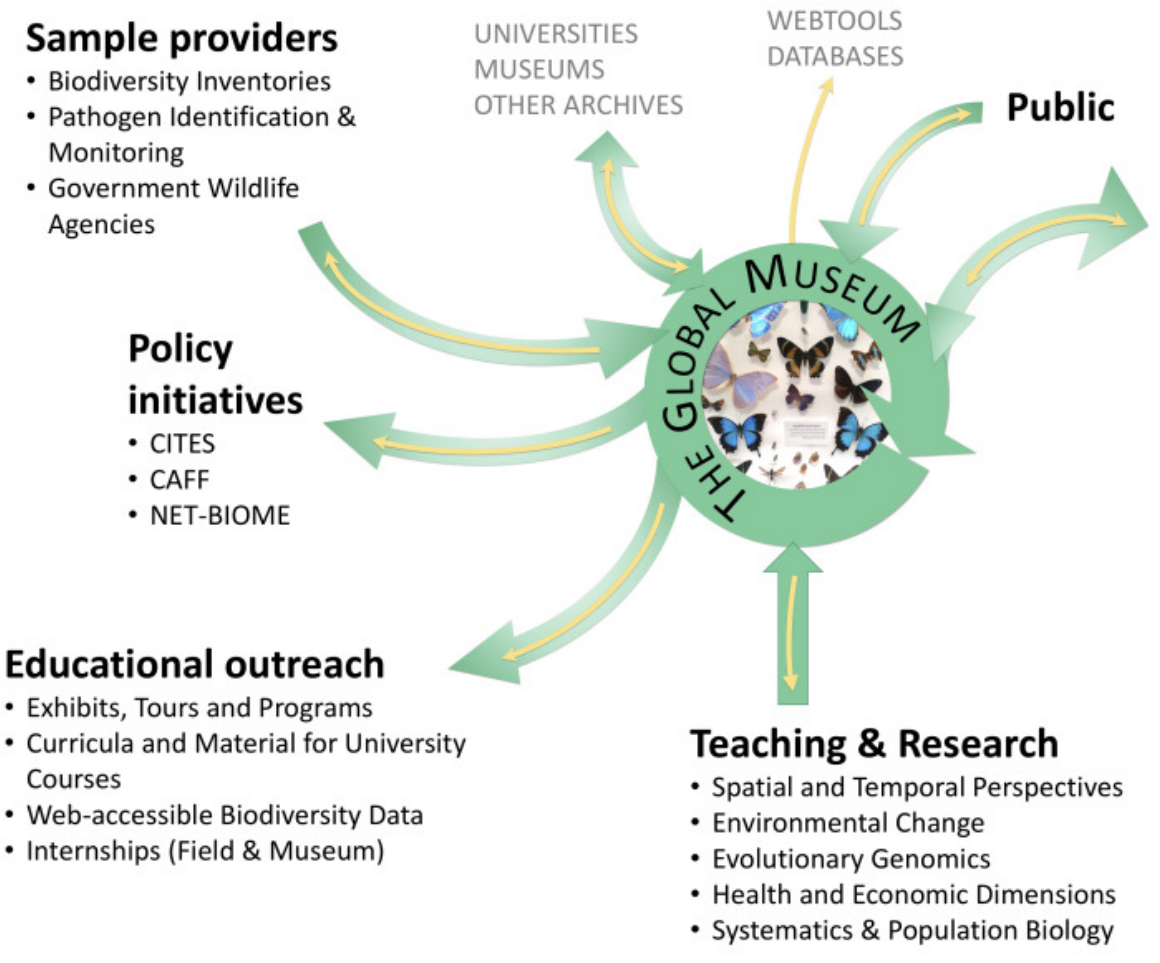

\section{Science}

Conservation Biology

Population Status \& Structure, Abundance, Bottlenecks, Invasives Ecology

Distribution, Migration, Food Webs, Dispersal, Invasives, Stable Isotopes Emerging Pathogen Detection Identification, Monitoring Host Switching, Range Expansion Evolution

Response to Climate Change, Genome Evolution, Hybridization, Demography 